\title{
Data Summary Report: M-Area Western Sector Remediation Project
}

by

W. E. Jones

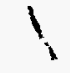

Westinghouse Savannah River Company

Savannah River Site

Aiken, South Carolina 29808

J. R. Jarosh

J. L. Simmons

S. L. Baxiey.

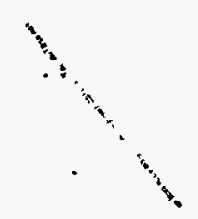

DOE Contract No. DE-AC09-96SR18500

This paper was prepared in connection with work done under the above contract number with the U.S. Department of Energy. By acceptance of this paper, the publisher and/or recipient acknowledges the U.S. Government's right to retain a nonexclusive, royalty-free license in and to any copyright covering this paper, along with the right to reproduce and to authorize others to reproduce all or part of the copyrighted paper.

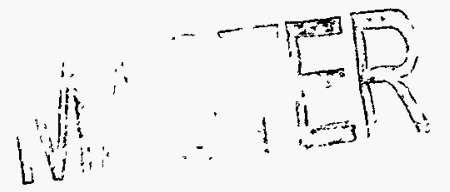




\section{DATA SUMMARY REPORT: M-AREA WESTERN SECTOR REMEDIATION PROJECT (U)}

April 1998

W. E. Jones

T. R. Jarosh

J. L. Simmons

S. L. Baxley

Environmental Sciences and Technology Department

Savannah River Technology Center

Westinghouse Savannah River Company

Savannah River Site

Aiken, SC 29808

Prepared for the U.S. Department of Energy under Contract No. DE-AC-09-96SR18500 


\section{DISCLAIMER}

This report was prepared as an account of work sponsored by an agency of the United States Government. Neither the United States Government nor any agency thereof, nor any of their employees, makes any warranty, express or implied, or assumes any legal liability or responsibility for the accuracy, completeness, or usefulness of any information, apparatus, product, or process disclosed, or represents that its use would not infringe privately owned rights. Reference herein to any specific commercial product, process, or service by trade name, trademark, manufacturer, or otherwise does not necessarily constitute or imply its endorsement, recommendation, or favoring by the United States Government or any agency thereof. The views and opinions of authors expressed herein do not necessarily state or reflect those of the United States Government or any agency thereof.

This report has been reproduced directly from the best available copy.

Available to DOE and DOE contractors from the Office of Scientific and Technical Information, P.O. Box 62, Oak Ridge, TN 37831; prices available from (615) 576-8401.

Available to the public from the National Technical Information Service, U.S. Department of Commerce; 5285 Port Royal Road, Springfield, VA 22161. 


\section{DISCLAIMER}

Portions of this document may be illegible electronic image products. Images are produced from the best available original document. 


\section{Contents}

Acronym List $\quad$ iii

1.0 INTRODUCTION 1

2.0 FIELD ACTIVITIES

2.1 Soil Coring 2

2.2 Geophysical Logging 3

2.3 Soil Sampling 4

2.4 Investigation Derived Waste $\quad \cdot 6$

2.5 Health and Safety Oversight 6

$\begin{array}{ll}\text { 3.0 SUMMARY } & 7\end{array}$

4.0 REFERENCES

FIGURES

Figure 1. M-Area Western Sector Soil Boring Location Map

Figure 2. WS-1 Lithology and Analytical Results

Figure 3. WS-3 Lithology and Analytical Results

Figure 4. WS-5 Lithology and Analytical Results

\section{TABLES}

Table 1. WS-1 TCE and PCE Soil Concentrations

Table 2. WS-3 TCE and PCE Soil Concentrations

Table 3. WS-5 TCE and PCE Soil Concentrations

\section{APPENDICES}
A Daily Activities Logs
B Field Geologic Logs
C Geophysical Logs
D Soil Sampling Field Log and Duplicate Analyses Comparison Summary
E Atmospheric Monitoring/Investigation Derived Waste Field Screening 


\section{Acronym List}

$\begin{array}{ll}\text { cc } & \text { cubic centimeters } \\ \text { dia } & \text { diameter } \\ \mathrm{ft} & \text { foot or feet } \\ \mathrm{ft} \text { bls } & \text { feet below land surface } \\ \text { g/cc } & \text { grams per cubic centimeter } \\ \text { in. } & \text { inch(es) } \\ \text { mm } & \text { millimeter(s) } \\ \text { ng/g } & \text { nanograms of constituent per gram of bulk sediment } \\ \text { PCE } & \text { perchloroethylene; also known as tetrachloroethylene } \\ \text { ppbw } & \text { parts per billion-weight based } \\ \text { ppm } & \text { parts per million } \\ \text { TCE } & \text { trichloroethylene } \\ \text { SRS } & \text { Savannah River Site } \\ \text { WSRC } & \text { Westinghouse Savannah River Corporation } \\ & \end{array}$




\subsection{INTRODUCTION}

M Area is located in the northern section of the Savannah River Site (SRS). The area includes facilities that fabricated reactor fuel and target assemblies for SRS reactors and a former settling basin which has been capped and closed under Resource Conservation and Recovery Act requirements. The M-Area western and southern portions outside the former fabrication facilities comprise undeveloped areas mainly covered by pine woods. A Carolina Bay is also located in the southern sector.

Past activities in M Area resulted in release of industrial cleaning solvents, primarily trichloroethylene (TCE) and perchloroethylene (PCE), to the subsurface. SRS has pursued an aggressive path toward environmental remediation of M-Area chlorinated solvents in both the saturated and vadose zones. M Area remediation actions include vadose zone vapor recovery, groundwater recovery (pump-and-treat) in the central $A / M$ area, and in situ air-stripping/recirculation wells located along the 500 parts per billion (ppb) TCE isocontour in the southern sector (WSRC, 1996).

This investigation provides stratigraphic and constituent concentration data for the MArea western sector in situ remedial system location and design.

\subsection{FIELD ACTIVITIES}

The investigation included field geologic logging of core and geophysical logging of completed coreholes from three (the two outer and central, WS-1, WS-3, and WS-5) of five surveyed western sector locations (Figure 1). These locations were selected by inferring the groundwater plume $500 \mathrm{ppb}$ TCE isocontour. The two locations not drilled (WS-2 and WS-4), will be evaluated and their locations potentially refined for future subsurface characterization based on data provided by this investigation. Core samples were collected for head-space TCE and PCE analysis. Field activities began on January 26, 1998 and concluded on February 17, 1998. Field technical and health and safety oversight were provided by Savannah River Technology Center's Environmental Restoration Technologies Section. Field activities were performed under the guidance of Westinghouse Savannah River Company (WSRC) procedure 3Q5, Hydrogeologic Data Collection (U) (WSRC, 1997) and the Site-Specific Health and Safety Plan for Western Sector Soil Borings (WSRC, 1998).

Samples for head-space analysis were collected at approximately five-foot (ft) vertical intervals in the Water Table Aquifer/M-Area Aquifer Zone (i.e., above the bottom of the Warley Hill Formation, informally called the "Green Clay") and at approximately two-ft vertical intervals in the Lost Lake Aquifer (i.e. Congaree Formation and Four Mile Member of the Fishburne Formation). Exact sample locations were additionally determined by selecting the sand zones overlying clay zones at the interface of sand and silt/clay layers. These silt/clay layers varied in thickness from less than one centimeter to 
over one meter. Constituent concentrations were anticipated to potentially be higher above lower-permeability zones than below. Coreholes were terminated upon encountering the Lang Syne Member of the Rhems Formation (also known as the Ellenton Formation). A detailed review of M-Area geology is presented in Hydrogeologic Framework for the A/M Area (U) (WSRC, 1995).

\subsection{SOIL CORING}

Drilling and coring were performed by Alliance Environmental, Inc., Aiken, South Carolina. Each of the thee locations were drilled by mud-rotary method (6-inch (in.)diameter (dia.) bit) to a depth of $125 \mathrm{ft}$ below land surface (bls). Mud-rotary coring (94 millimeter (mm), double-tube wireline core) was performed from $125 \mathrm{ft}$ bls to the top of the Lang Syne Member. Where possible, the uppermost five $\mathrm{ft}$ of the Lang Syne Member was obtained to verify the entire Lost Lake Aquifer had been sampled. Recovered cores were extruded into polyvinyl chloride troughs for immediate soil sample collection for head-space analysis, followed by lithologic description, and archiving. Bentonite based drilling fluid (or "mud") was used to maintain corehole integrity. Core recovery percentage was generally good to very good, often 100 percent. Summary illustrations of lithology, TCE, and PCE concentrations in regard to elevation for locations WS-1, WS3 , and WS-5 are presented in Figures 2,3, and 4, respectively. Daily field activity logs are included as Appendix A. Field geologic logs are included as Appendix B.

The three locations were drilled in numerical order (WS-1, WS-3, and WS-5), from southeasternmost to northwesternmost. A synopsis of the geology and drilling encountered for each location follows.

\section{Corehole WS-1}

The survey stake for WS-1 indicated a location of N100807.95, E45843.97, elevation $354.29 \mathrm{ft}$. Straight drilling to a depth of $125 \mathrm{ft}$ bls and initial coring and sampling from $125 \mathrm{ft}$ bls took place on January 28, 1998. Coring was completed to a total depth of 242 $\mathrm{ft}$ bls on January 29, 1998. The "Green Clay"/Congaree Formation contact (Water Table/Lost Lake Aquifer delineation) was picked at a clay/sand contact at $160 \mathrm{ft}$ bls. A gray, clay zone was identified from 180 to $199.5 \mathrm{ft}$ bls. The clay zone caused slow, difficult drilling. One ft- to $1.5 \mathrm{ft}$-thick sands occur within the clay zone between 188 and $194 \mathrm{ft}$ bls. This clay likely comprises the portion of the Fourmile Member of the Fishburne Formation which separates the Lost Lake Aquifer into the Upper and Lower Lost Lake Aquifers. The Lang Syne Member (bottom of the Lost Lake Aquifer) was identified at a sharp contact (overlying poorly sorted, coarse grained material underlain by a variegated clay) at $237 \mathrm{ft}$ bls.

\section{Corehole WS-3}

The WS-3 survey stake indicated a location of N101415.39, E44739.51, elevation 372.86 $\mathrm{ft}$ (Note: this elevation is about $20 \mathrm{ft}$ higher than locations WS-1 and WS-5, therefore 
geologic formations were expected to be encountered at greater depths). Straight drilling to a depth of $125 \mathrm{ft}$ bls took place on February 2, 1998. Coring and sampling were performed on February 5 and 6, 1998. Coring was completed to a total depth of $277 \mathrm{ft}$ bls. The "Green Clay"/Congaree Contact (Water Table/Lost Lake Aquifer delineation) was picked at a clay/sand contact at $172.6 \mathrm{ft}$ bls. The "Green Clay" in WS-3 was well defined compared to WS-1. The thick, gray clay portion of the Fourmile Member identified at WS- 1 was not observed in WS-3 core. Three clay zones, each from $0.25 \mathrm{ft}-$ to one-ft thick, were identified between 201 and $226 \mathrm{ft}$. One or more of these clays may be equivalent to the clay identified in WS-1. At WS-3, the Lost Lake Aquifer is not considered differentiated into Upper and Lower zones due to lack of a well developed clay portion of the Fourmile Member. The Lang Syne Member (bottom of the Lost Lake Aquifer) was picked at $270.5 \mathrm{ft}$ bls, where a black, clayey silt/silty clay was encountered. The Lang Syne Member contact was expected even before the core was retrieved, due to sudden hard drilling and a darkening of the drilling mud.

\section{Corehole WS-5}

The WS-5 survey stake indicated a location of N102887.97, E44259.99, elevation 355.65 ft. Straight drilling to a depth of $125 \mathrm{ft}$ bls was performed on February 9, 1998. Coring to a total depth of $249 \mathrm{ft}$ bls and sampling were performed on February 10 and 11, 1998. Drilling mud circulation was lost at $247 \mathrm{ft}$ bls. The "Green Clay"/Congaree contact (Water-Table/Lost Lake Aquifer deliniation) was picked at $162 \mathrm{ft}$ bls, where a dark green (probably glauconitic) zone occurs. Although clay laminae were common to a depth of $224 \mathrm{ft}$ bls, and a one-ft thick clayey zone with clay beds 1 to 1.5 in. thick occurred at a depth of 202.2 to $203.2 \mathrm{ft}$, no significant clay zone (such as at WS-1) was present. As with WS-3, the Lost Lake Aquifer is not considered differentiated into Upper and Lower zones due to lack of a well developed clay portion of the Four Mile Member. Drilling mud circulation loss precluded additional coring to define the exact depth of the Lang Syne Member (bottom of Lost Lake Aquifer). The Lang Syne Member is not considered to lie far below WS-5 total depth, probably within ten feet, based on correlation with existing data.

\subsection{GEOPHYSICAL LOGGING}

Each borehole was geophysically logged by Graves Environmental \& Geotechnical Services, Inc. following completion to total depth. Geophysical log parameters included caliper (borehole diameter), natural gamma, and resistivity. Each geophysical log was compared to the field geological log to verify the presence of sandy and clayey horizons. Comparison was good for all three coreholes. Two observations are noted: 1) Even relatively thin clay layers yield a readily distinguishable increase in natural gamma measurement; and 2) The significant clay portion of the Fourmile Member did not yield as large a gamma signature as anticipated, though two clay peaks are present and the sandy zone observed within this clay is reflected by the dip between these two gamma peaks. Corehole geophysical logs are included as Appendix C. 


\subsection{SOIL SAMPLING}

Depth discrete soil samples were collected for TCE and PCE analysis. Samples were collected at approximately five-ft vertical intervals in the Water Table Aquifer (from 125 $\mathrm{ft}$ bls to the bottom of the "Green Clay"), and at approximately two-ft vertical intervals in the Lost Lake Aquifer (bottom of the "Green Clay" to top of the Lang Syne Member). Additional samples were collected and/or exact sample collection points were determined by collecting samples from sandy zones overlying clay lenses where applicable. Soil samples were collected immediately upon recovered core extrusion. Soil sample date, time of collection, sample identification, depth, and description were recorded in a field log book. Copies of applicable pages of the sample log book are included in Appendix D.

Soil samples comprised approximately 2 to $3 \mathrm{cc}$ of the groundwater-saturated bulk sediment. Samples were collected immediately upon core retrieval by first removing 5 to $10 \mathrm{~mm}$ of the core surface to assure drilling mud and corehole slough material were avoided, then pushing a clean 12-mm-dia. sample tube (a modified plastic syringe) into the core center. Sampling syringes were cleaned between samples by brushing and rinsing with isopropanol followed by a deionized water rinse.

Upon collection, depth discrete bulk sediment samples were immediately extruded into $22.5 \mathrm{cc}$ borosilicate vials. Using a mechanized pipet, $5 \mathrm{cc}$ of deionized water was added as a suspending solution, and each vial was sealed by crimping an aluminum cap around a Teflon®-lined butyl rubber septum. The sample was labeled and placed in a chilled ice chest for transport to an onsite analytical laboratory. At the laboratory, refrigerated storage was maintained until samples were analyzed (a one to six day period, typically one to three days). Prior to analysis, sample-containing vials were weighed. The amount of sediment in a given sample was determined by subtracting the average vial plus water weight (previously determined) from the vial plus water and soil weight. Each vial was analyzed using a Hewlett Packard (HP) 5890 Semes II gas chromatograph equipped with an electron capture detector, and flame ionization detector, an HP 19395 headspace sampler, and a $60 \mathrm{~m}$. widebore capillary column coated with an intermediate-polarity silicone phase (Supelco, Vocol).

Flow and temperature conditions recommended by the manufacturers were used. The instrument was calibrated using vials containing water of known concentrations. The conditions in the vials (headspace volume, suspension volume, etc.) were standardized to maintain the proportionality between the sediment concentration and the headspace concentration. For example, a heated sample bath (70 degrees Celsius) maximizes transfer of volatile constituents into the headspace for analysis and standardizes volatile constituent transfer conditions. For each sample, a duplicate sample was obtained in case of sample breakage. Approximately 20 percent of the duplicate samples were analyzed as a quality assurance method of evaluating "same sample" variation (Appendix D). Unlike groundwater samples, soil is not a homogeneous matrix. Greater variablity in soil sample duplicate analysis (than in water) is expected. Agreement between original samples and 
sample duplicates is generally good, usually less than a 25 percent difference in concentrations is reported.

Analytical results are reported in units of nanograms of constituent per gram of bulk sediment (ng/g), or ppbw (parts per billion-weight based). Analytical results are summarized in Tables 1,2 , and 3, respectively. The field sampling $\log$ and duplicate analyses summary are presented in Appendix D. Note that the samples designations for WS- 3 are mis-labeled as WS- 2 in the sample log. These samples were analyzed using the WS-2 designation. The correction to WS- 3 is made in this text.

\section{Analytical Results Discussion}

Highest concentrations for all three cores are reported from the Lost Lake Aquifer rather than the Water Table Aquifer. Soil sample maximum concentrations from core WS-1 (see Figure 2, Table 1) are lower than for cores WS-3 and WS-5. Maximum concentrations are in the range of 14 to $16 \mathrm{ppbw}$. Samples from the upper Lost Lake contain higher concentrations of PCE than TCE, while samples from the lower Lost Lake generally contain higher concentrations of TCE than PCE.

Groundwater concentrations can be approximated on a weight basis using soil concentrations. Assuming that 33 percent of a sample is groundwater-filled pore space, and a weight of $1 \mathrm{~g} / \mathrm{cc}$ for water and $2.6 \mathrm{~g} / \mathrm{cc}$ for soil (comprising 67 percent of a sample), the coefficient by which soil concentrations can be related to groundwater concentrations should be equal to the total weight-based concentration divided by the groundwater fraction of the total weight-based concentration, i.e.,

$$
\text { coefficient }=\frac{0.33(1 \mathrm{~g} / \mathrm{cc})+0.67(2.6 \mathrm{~g} / \mathrm{cc})}{0.33(1 \mathrm{~g} / \mathrm{cc})}=6.3
$$

For example, a soil weight-based concentration of $10 \mathrm{bbpw}$ should reflect about 60.3 ppbw for the groundwater in the soil sample. For core WS-1, this would indicate maximum groundwater concentrations in the range of 88 to $102 \mathrm{ppbw}$.

Soil samples from core WS-3 typically yielded TCE and PCE concentrations less than 10 ppbw. The maximum concentration, $63 \mathrm{ppbw}$ PCE, is from a depth of $226 \mathrm{ft} \mathrm{bls}$, in the vertically central portion of the Lost Lake Aquifer. The next highest concentrations, 39.7 and $42.5 \mathrm{ppbw}$, are from the lower portion of the Lost Lake Aquifer, at depths of 258 and $264 \mathrm{ft}$ bls, respectively (Figure 3, Table 2). These three highest concentrations should be equivalent to approximate groundwater concentrations of 397, 250, and $268 \mathrm{ppbw}$, respectively. As previously mentioned, note that in the field sample log (Appendix D), samples from WS-3 are mis-labeled as WS-2 samples. The correction to WS-3 is made in this text.

Soil samples from core WS-5 yielded the highest TCE concentrations of the three cores (Figure 4, Table 3). PCE concentrations were very low compared to TCE for WS-5. 
Maximum TCE concentration was $104.7 \mathrm{ppbw}$, for a depth of $180 \mathrm{ft}$ bls. The three second highest TCE concentrations, $62.3,56.8$, and $53.9 \mathrm{ppbw}$, from depths of 178,182 , and $190 \mathrm{ft}$ bls, are from vertically nearby samples, all of which are in the upper portion of the Lost Lake Aquifer. The next highest TCE concentrations are 31.4, 25.6, and 16.4 ppbw, from depths of 204, 220, and $210 \mathrm{ft}$ bls, respectively. Samples from the lowermost portion of the Lost Lake exhibited relatively low ( $<5 \mathrm{ppbw}$ ) TCE concentrations. The highest WS-5 estimated groundwater-equivalent TCE concentrations are in the order of 200 to 660 ppbw.

\subsection{INVESTIGATION DERIVED WASTE}

Investigation derived waste (DW) comprises materials such as drilling mud, well development or purge water, and personal protective equipment which may entrain, absorb, or adsorb constituents of concern in exceedence of a given action limit. For this project, the constituents of concern are TCE and PCE. The primary potential IDW material anticipated was drilling mud. The action levels established for the project were 52 parts per million (ppm) for TCE and 12 ppm for PCE. Previous experience drilling in $M$ Area indicated that the potential for drilling mud to exceed these concentrations was very low. The corehole locations were within the dissolved plume, but without vadose zone source, in areas not expected to have groundwater TCE or PCE concentrations exceeding $1 \mathrm{ppm}$.

To verify that IDW action levels were not exceeded, drilling mud samples were obtained for head-space analysis similar to soil samples. Drilling mud analyses indicated TCE concentrations below detection limits and PCE concentrations from 0.3 to $1.3 \mathrm{ppbw}$ from locations WS-1 and WS-3, respectively. Due to lost circulation, no drilling mud was available for sampling from WS-5.

Additionally, field screening was performed by WSRC Environmental Restoration personnel using an RCLS 5000 Chlorinated Vapor Organic Analyzer. Chlorinated organic vapor measurements of $1 \mathrm{ppm}$ are reported for WS-1 drilling mud and core for January 28,1998 . A low-battery warning is also reported for measurements this date. The following day, a series of measurements obtained from WS-1 drilling mud and core from 144 to $189 \mathrm{ft}$ bls indicated no measurable chlorinated vapor concentrations. Field documentation for $\mathrm{DWW}$ and breathing zone chlorinated vapor measurements are included as Appendix E.

\subsection{HEALTH AND SAFETY OVERSIGHT}

The primary health and safety guidance document for the Western Sector Project was Site-Specific Health and Safety Plan for Western Sector Borings (Q-SHP-G-00037, Rev. 2, January 22, 1998; WSRC, 1998). The project health and safety pre-job briefing was conducted on January 26,1998, by the project health and safety plan author/WSRC Environmental Restoration Department Occupational Safety and Health Coordinator. This briefing was attended by the primary project personnel, including project 
management, drillers, the field health and safety officer/technical oversight, and the field sampler.

The investigation area's primary constituents of concern (TCE and PCE) are volatile organic compounds, chlorinated solvents, which begin to convert to a gas-phase upon contact with the atmosphere. At no time during drilling, geologic logging, or sampling activities were any chlorinated-solvent-like odors noted. Field screening for breathingspace chlorinated organic compound concentrations were performed to verify concentrations below action levels specified in the project health and safety plan. Breathing-space measurements were performed at the same time and using the same chlorinated organic vapor measurement device as for the IDW field screening. Breathing zone measurements of $1 \mathrm{ppm}$ were obtained during WS-1 field activities on January 28, 1998 (the instrument also had a low battery indication on this date). The following day, breathing-space screening indicated readings of zero $\mathrm{ppm}$. Of the three project drilling locations, WS-1 was considered to be in the area of the groundwater plume which should yield the highest chlorinated compound concentrations. WS-1 was therefore considered as representing the "worst case" location in terms of health and safety risk. Because such low breathing-space concentrations were obtained at WS-1, additional breathing-space measurements from WS-3 and WS-5 locations were not required. Breathing-space measurements are included in Appendix E.

\subsection{SUMMARY}

The delineation of a groundwater TCE and PCE plume isoconcentration line of approximately $500 \mathrm{ppm}$, and associated detailed geologic information is required to design a groundwater remedial system for Lost Lake Aquifer in the SRS M-Area western sector. Three coreholes located approximately along this isoconcentration line were drilled by mud rotary technique between January 26, and February 17, 1998. Soil samples were obtained at $5 \mathrm{ft}$ vertical intervals from $125 \mathrm{ft}$ (approximate top of the Water Table Aquifer) to the approximate top of the Lost Lake Aquifer. Samples were obtained at approximately $2 \mathrm{ft}$ intervals throughout the Lost Lake Aquifer. Samples were also obtained at changes in lithology where sands overlay clays.

The lithology at the southeasternmost location, WS-1, includes a significant clay zone which separates the Lost Lake Aquifer into the Upper and Lower Lost Lake Aquifer zones. The two locations to the northwest, WS-3 and WS-5, did not exhibit this welldefined clay zone, thus the Lost Lake Aquifer in these locations cannot be as readily separated into identifiable Upper and Lower zones. This is consistent with the observed trend in aquitards becoming discontinuous and pinching-out and shallower aquifers coalescing toward the northwest. For example, there is a northerly disappearance of the "Green Clay" Confining Zone and coalescence of the Water Table or M-Area Aquifer with the Lost Lake Aquifer and Middle Sand Aquifer to form the Steed Pond Aquifer (see WSRC, 1995, et. Seq.) The Lost Lake Aquifer is identified between depths from approximately 160 to $173 \mathrm{ft}$ bls to 237 to $271 \mathrm{ft}$ bls in the M-Area western sector. 
Analytical results indicate WS-1 location TCE and PCE soil concentrations are lower than the other two locations. Maximum WS-1 soil concentrations are in the range of 14 to $16 \mathrm{ppbw}$ (approximately equivalent to 88 to $102 \mathrm{ppbw}$ groundwater concentrations). For WS-1, PCE concentrations exceed TCE concentrations in the upper Lost Lake Aquifer, and TCE concentrations exceed PCE concentrations in the lower Lost Lake Aquifer.

Soil samples from core WS-3 typically yield TCE and PCE concentrations less than 10 ppbw. The maximum concentration, $63 \mathrm{ppbw} \mathrm{PCE}$, is from a depth of $226 \mathrm{ft}$ bls, in the vertically central portion of the Lost Lake Aquifer. The next highest concentrations, 39.7 and $42.5 \mathrm{ppbw}$, are from the lower portion of the Lost Lake Aquifer, at depths of 258 and $264 \mathrm{ft}$ bls, respectively. These three highest concentrations should be equivalent to approximate groundwater concentrations of 397,250 , and $268 \mathrm{ppbw}$, respectively.

Soil samples from core WS-5 yield the highest TCE concentrations of the three cores. PCE concentrations were very low compared to TCE. Maximum TCE concentration was $104.7 \mathrm{ppbw}$, for a depth of $180 \mathrm{ft}$ bls. The three second highest TCE concentrations, $62.3,56.8$, and $53.9 \mathrm{ppbw}$, from depths of 178,182 , and $190 \mathrm{ft}$ bls, are from vertically nearby samples, all of which are in the upper portion of the Lost Lake Aquifer. The next highest TCE concentrations are 31.4, 16.4, and $25.6 \mathrm{ppbw}$, from depths of 204, 210, and $220 \mathrm{ft}$ bls, respectively. Samples from the lowermost portion of the Lost Lake for WS-5 exhibited relatively low ( $<5 \mathrm{ppbw}$ ) TCE concentrations. The highest WS-5 estimated groundwater-equivalent TCE concentrations are in the order of 200 to $660 \mathrm{ppbw}$.

\subsection{REFERENCES}

WSRC (Westinghouse Savannah River Company), 1995. Hydrogeologic Framework for the AMM Area (U), SRS: USDOE Report WSRC-RP-95-52, February 1995, Aiken, SC.

WSRC (Westinghouse Savannah River Company), 1996. Estimating the Extent and Thickness of DNAPL Within the A/M Area of the Savannah River Site (U), SRS: USDOE Report WSRC-RP-96-0574, December 20, 1996, Aiken, SC.

WSRC (Westinghouse Savannah River Company), 1997. Hydrogeologic Data Collection Procedures and Specifications (U), SRS: Procedure Manual 3Q5, Rev. 2, June 30, 1997, Aiken, SC.

WSRC (Westinghouse Savannah River Company), 1998. Site-Specific Health and Safety Plan for Western Sector Soil Borings (Rev. 2), Environmental Restoration Department Safety \& Health Plan Q-SHP-G-00037, January 22, 1998, Aiken, SC. 
Data Summary Report: M-Area

Western Sector Remediation Project (U)
WSRC-TR-98-00089

April 1998

\section{FIGURES}


Location of Western Sector Soil Borings

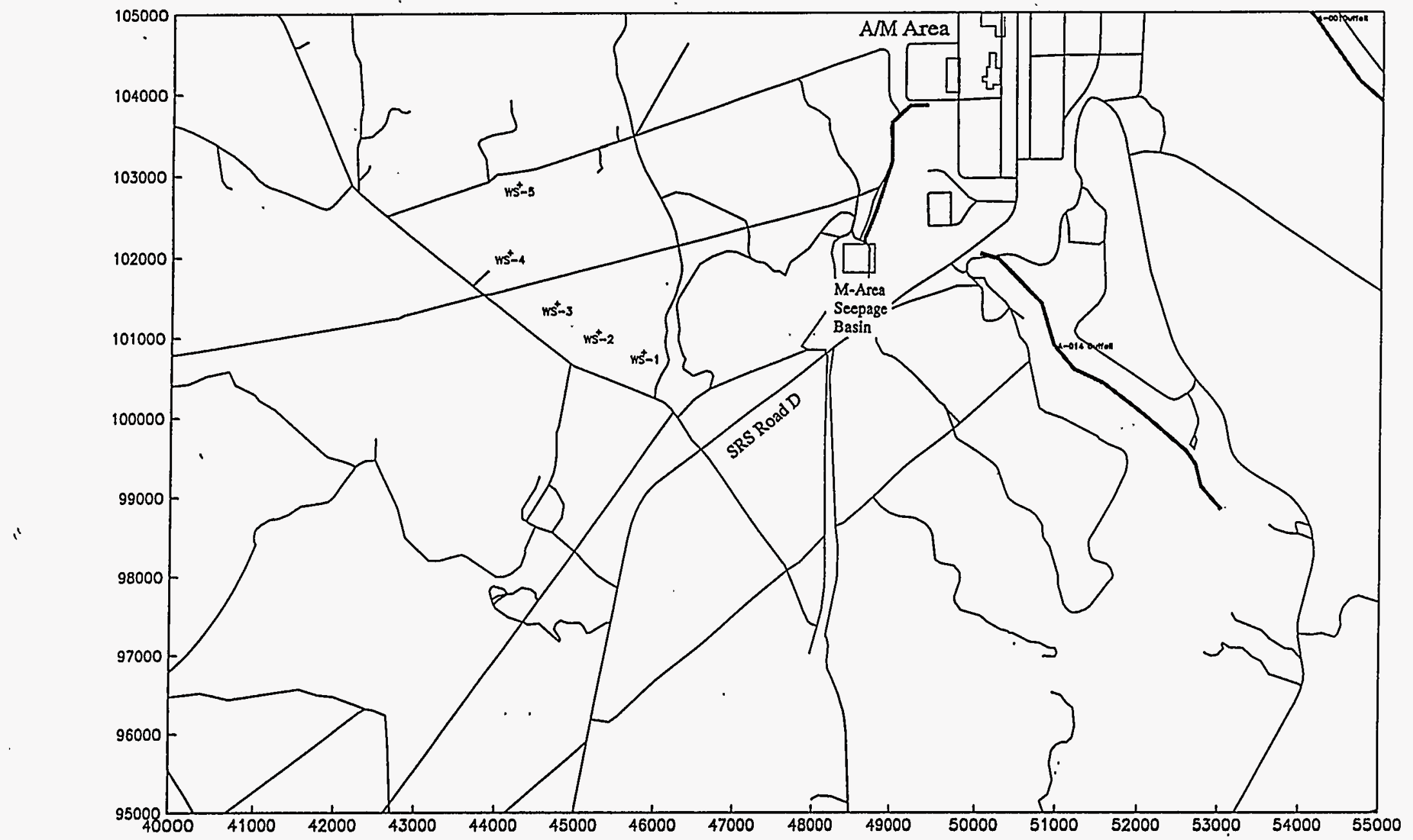

Figure 1. M-Area Western Sector Corehole Location Map 
Data Summary Report: M-Area

Western Sector Remediation Project (U)

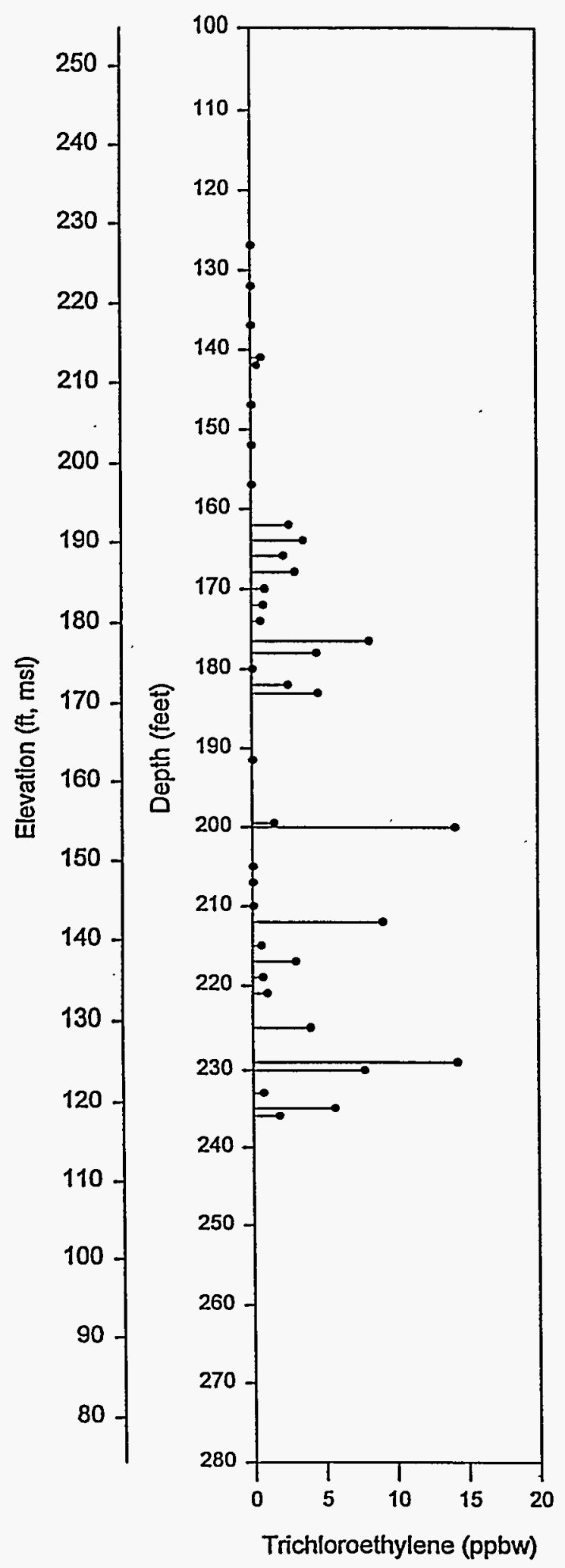

WS-1

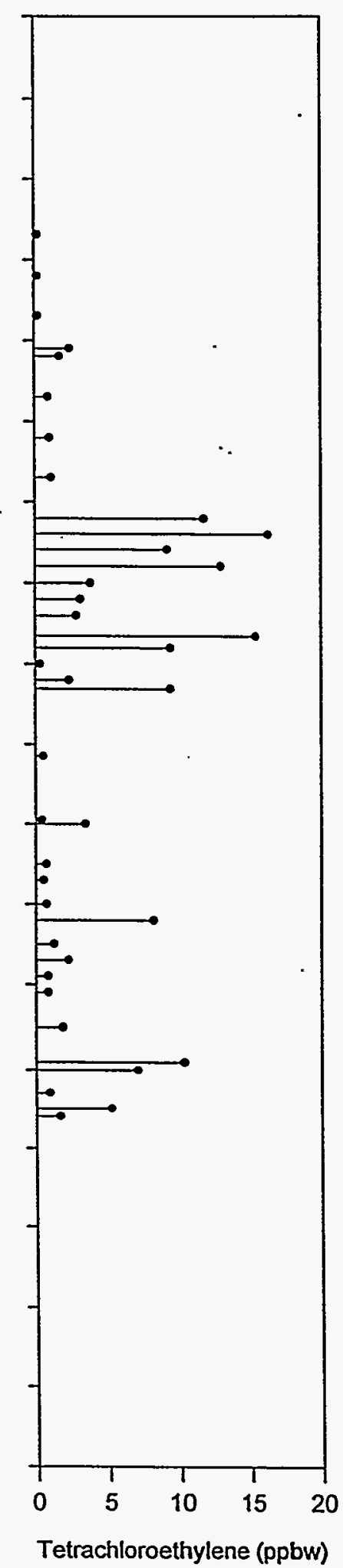

Figure 2. WS-1 Lithology and Analytical Results 


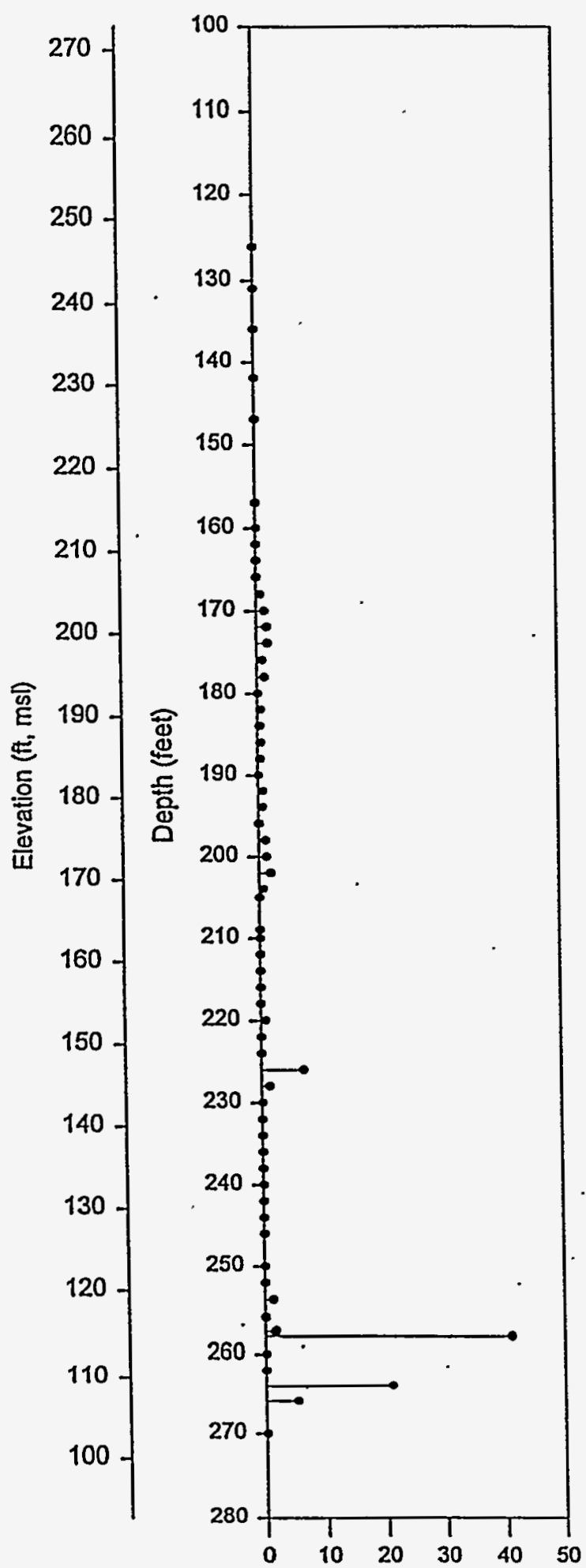

Trichloroethylene (ppbw)
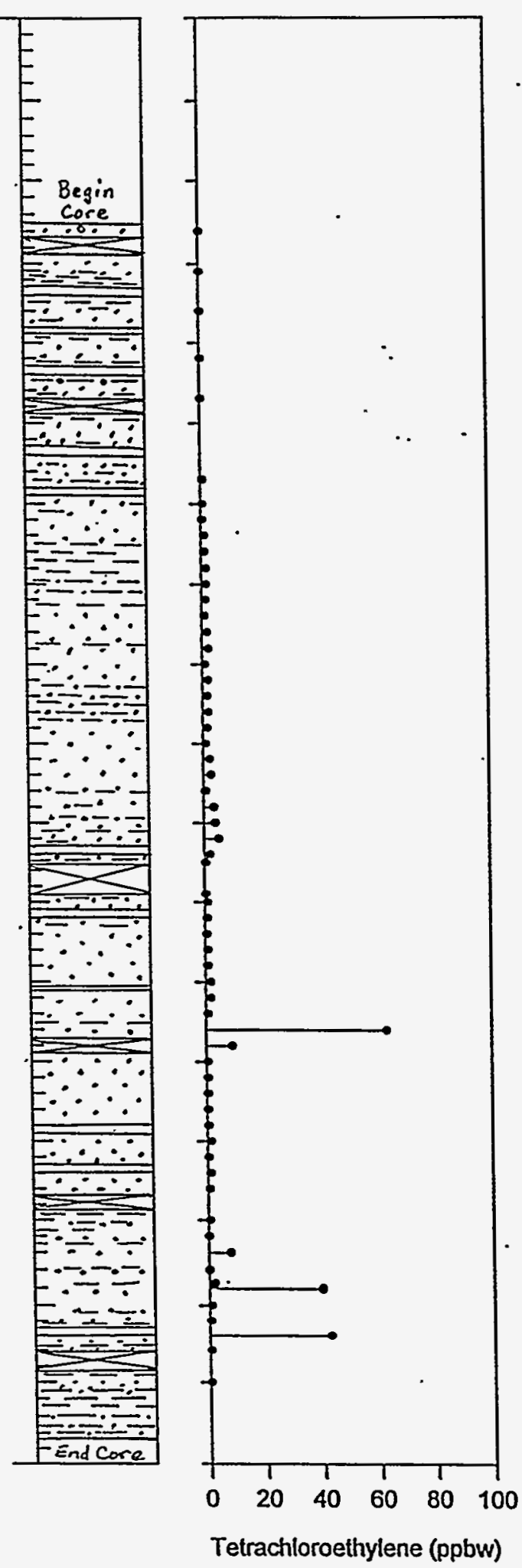

Figure 3. WS-3 Lithology and Analytical Results 


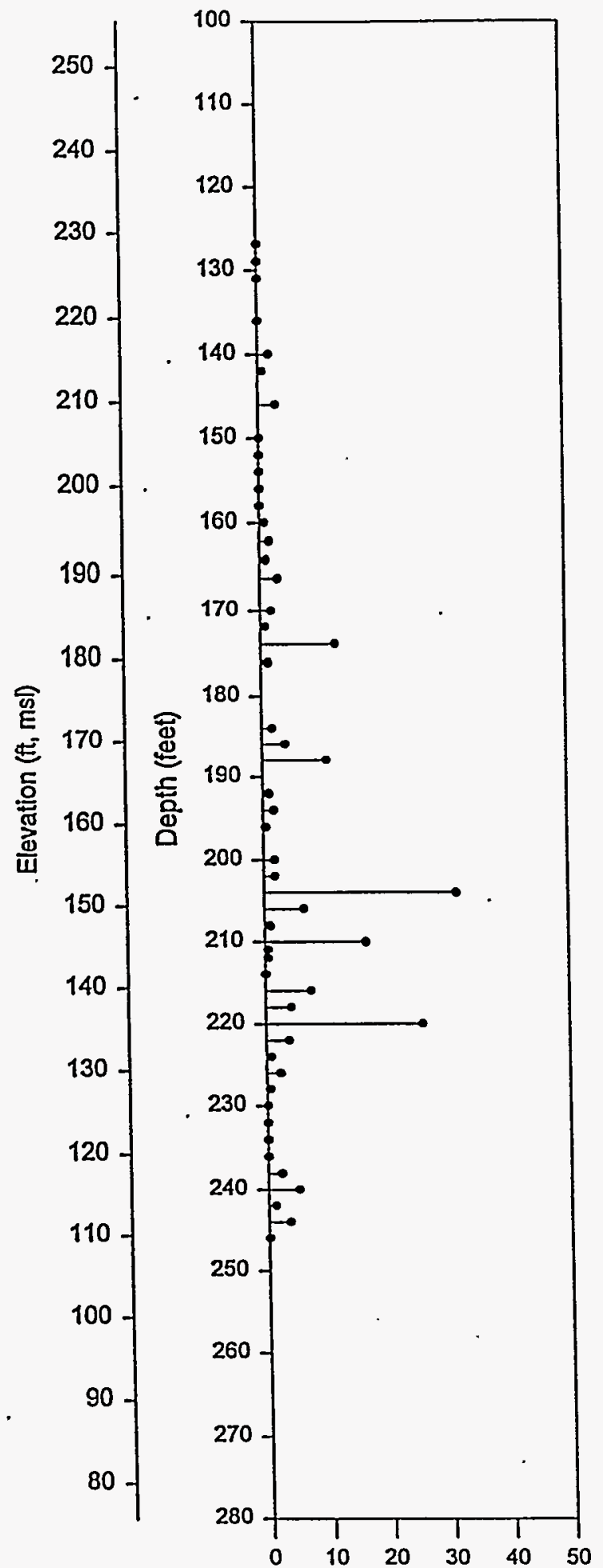

Trichloroethylene (ppbw)
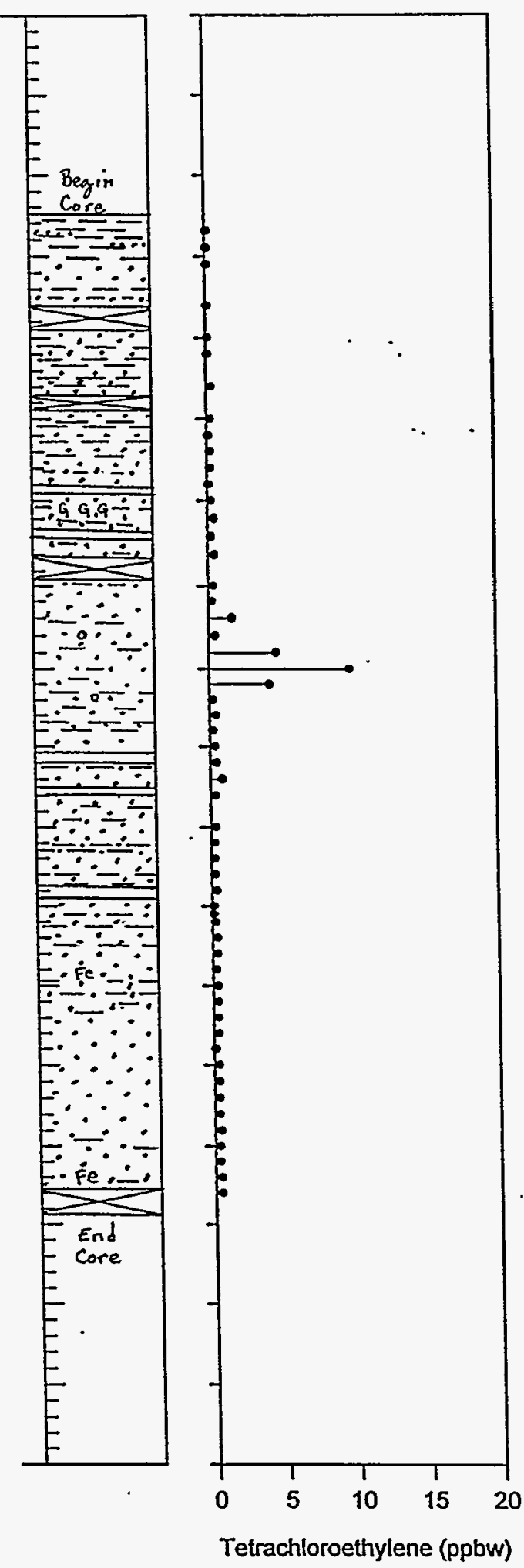

Figure 4. WS-5 Lithology and Analytical Results 
WS-1

Depth, ft

127

132

137

141

142

147

152

157

162

164

166

168

170

172

174

176.5

178

180

182

183

191.5

199.5

200

205

207

210

212

215

217

219

221

225

229

230

233

235

236

MUD

\section{Soil Concentration}

TCE

ppb, w/w

0.0

0.0

0.0

0.7

0.4

0.0

0.0

0.0

2.6

3.6

2.2

3.0

0.9

0.8

0.6

8.2

4.5

0.0

2.5

4.6

0.0

1.5

14.2

0.0

0.0

0.0

9.1

0.6

3.0

0.7

1.0

4.0

14.3

7.8

0.7

5.7

1.8

0.0
PCE

ppb, w/w

wt. corr.

0.2

0.2

0.2

2.4

1.7

0.9

1.0

1.1

11.7

16.3

9.2

12.9

3.8

3.1

2.8

15.4

9.4

0.3

2.3

9.4

0.5

0.4

3.4

0.7

0.5

0.7

8.2

1.2

2.2

0.8

0.8

1.8

10.3

7.1

0.9

5.2

1.6

1.3

Table 1. WS-1 TCE and PCE Soil Concentrations 
WS-3

Depth, ft

126

131

136

142

147

147

157

160

162

164

166

168

170

172

174

176

178

180

182

184

186

188

190

192

194

196

198

200

202

204

205

209

210
Soil Concentration TCE

PCE

ppb, w/w

wt. corr

0.0

0.0

0.0

0.0

0.0

0.0

0.0

0.0

0.0

0.0

0.6

1.2

1.6

1.7

0.8

1.1

0.0

0.5

0.4

0.5

0.4

0.0

0.7

0.6

0.0

1.0

1.1

1.8

0.6

0.0

0.0

0.0 $\mathrm{ppb}, \mathrm{w} / \mathrm{w}$

wt. corr.

0.2

0.2

0.3

0.3

0.3

0.3

0.6

0.5

0.4

1.0

1.0

1.5

1.4

1.2

0.9

1.6

2.0

0.8

1.8

1.5

1.8

1.4

0.8

2.1

2.5

0.7

3.4

3.8

5.0

1.9

0.5

0.4

0.9

Table 2. WS-3 TCE and PCE Soil Concentrations 


\begin{tabular}{|c|c|c|}
\hline WS-3 & $\begin{array}{l}\text { Soil Conce } \\
\text { TCE }\end{array}$ & PCE \\
\hline Depth, ft & $\begin{array}{l}\text { ppb, w/w } \\
\text { wt. corr. }\end{array}$ & $\begin{array}{l}\text { ppb, w/w } \\
\text { wt. corr. }\end{array}$ \\
\hline 212 & 0.0 & 0.8 \\
\hline 214 & 0.0 & 0.6 \\
\hline 216 & 0.0 & 0.9 \\
\hline 218 & 0.0 & 0.9 \\
\hline 220 & 0.7 & 1.7 \\
\hline 222 & 0.0 & 1.7 \\
\hline 224 & 0.0 & 0.7 \\
\hline 226 & 6.8 & 63.0 \\
\hline 228 & 1.2 & 8.9 \\
\hline 230 & 0.0 & 0.4 \\
\hline 232 & 0.0 & 0.5 \\
\hline 234 & 0.0 & 0.5 \\
\hline 236 & 0.0 & 0.4 \\
\hline 238 & 0.0 & 0.5 \\
\hline 240 & 0.0 & 1.2 \\
\hline 242 & 0.0 & 0.4 \\
\hline 244 & 0.0 & 1.0 \\
\hline 246 & 0.0 & 0.6 \\
\hline 250 & 0.0 & 0.5 \\
\hline 252 & 0.0 & 0.1 \\
\hline 254 & 1.2 & 7.5 \\
\hline 256 & .0 .0 & 0.1 \\
\hline 257.5 & 1.6 & 1.8 \\
\hline 258 & 40.9 & 39.7 \\
\hline 260 & $0.0^{\circ}$ & 0.7 \\
\hline 262 & 0.0 & 0.4 \\
\hline 264 & 20.8 & 42.5 \\
\hline 266 & 5.1 & 0.4 \\
\hline 270 & 0.0 & 0.2 \\
\hline MUD & 0.0 & 0.3 \\
\hline
\end{tabular}

Table 2. WS-3 TCE and PCE Soil Concentrations (continued). 


\begin{tabular}{|c|c|c|}
\hline WS-5 & $\begin{array}{c}\text { Soil Conc } \\
\text { TCE }\end{array}$ & PCE \\
\hline Depth, ft & $\begin{array}{l}\text { ppb, w/w } \\
\text { wt. corr. }\end{array}$ & $\begin{array}{l}\text { ppb, w/w } \\
\text { wt. corr. }\end{array}$ \\
\hline 127 & 0.0 & 0.1 \\
\hline 129 & 0.0 & 0.1 \\
\hline 131 & 0.0 & 0.1 \\
\hline 136 & 0.0 & 0.1 \\
\hline 140 & 1.7 & 0.1 \\
\hline 142 & 0.6 & 0.1 \\
\hline 146 & 2.7 & 0.3 \\
\hline 150 & 0.0 & 0.2 \\
\hline 152 & 0.0 & 0.1 \\
\hline 154 & 0.0 & 0.2 \\
\hline 156 & 0.0 & 0.2 \\
\hline 158 & 0.0 & 0.1 \\
\hline 160 & 0.7 & 0.2 \\
\hline 162 & 1.5 & 0.4 \\
\hline 164 & 0.9 & 0.2 \\
\hline 166 & 2.8 & 0.4 \\
\hline 170 & 1.7 & 0.3 \\
\hline 172 & 0.7 & 0.2 \\
\hline 174 & 12.0 & 1.6 \\
\hline 176 & 1.0 & 0.4 \\
\hline 178 & 62.3 & 4.7 \\
\hline 180 & 104.7 & 9.8 \\
\hline 182 & 56.8 & 4.2 \\
\hline 184 & 1.6 & 0.2 \\
\hline 186 & 3.6 & 0.4 \\
\hline 188 & 10.3 & 0.2 \\
\hline 190 & 53.9 & 0.3 \\
\hline 192 & 0.8 & 0.4 \\
\hline 194 & 1.7 & 0.8 \\
\hline 196 & 0.4 & 0.3 \\
\hline 200 & 1.7 & 0.3 \\
\hline 202 & 1.7 & 0.2 \\
\hline 204 & 31.4 & 0.2 \\
\hline 206 & 6.2 & 0.2 \\
\hline 208 & 0.7 & 0.3 \\
\hline 210 & 16.4 & 0.1 \\
\hline
\end{tabular}

Table 3. WS-5 TCE and PCE Soil Concentrations 


$\begin{array}{ccc}\text { WS-5 } & \begin{array}{c}\text { Soil Concentration } \\ \text { TCE }\end{array} & \text { PCE } \\ \text { Depth, ft } & \text { ppb, w/w } & \\ & \text { wt. corr. } & \begin{array}{c}\text { ppb, w/w } \\ \text { wt. corr. }\end{array} \\ 210 & 16.4 & 0.1 \\ 211 & 0.5 & 0.1 \\ 212 & 0.5 & 0.2 \\ 214 & 0.0 & 0.3 \\ 216 & 7.2 & 0.3 \\ 218 & 3.9 & 0.2 \\ 220 & 25.6 & 0.3 \\ 222 & 3.5 & 0.3 \\ 224 & 0.7 & 0.3 \\ 226 & 2.1 & 0.3 \\ 228 & 0.5 & 0.1 \\ 230 & 0.0 & 0.3 \\ 232 & 0.0 & 0.3 \\ 234 & 0.0 & 0.3 \\ 236 & 0.0 & 0.3 \\ 238 & 2.1 & 0.4 \\ 240 & 4.8 & 0.3 \\ 242 & 1.1 & 0.3 \\ 244 & 3.3 & 0.4 \\ 246 & 0.0 & 0.4\end{array}$

Table 3. WS-5 TCE and PCE Soil Concentrations (continued) 
APPENDIX A

Daily Activities Logs 


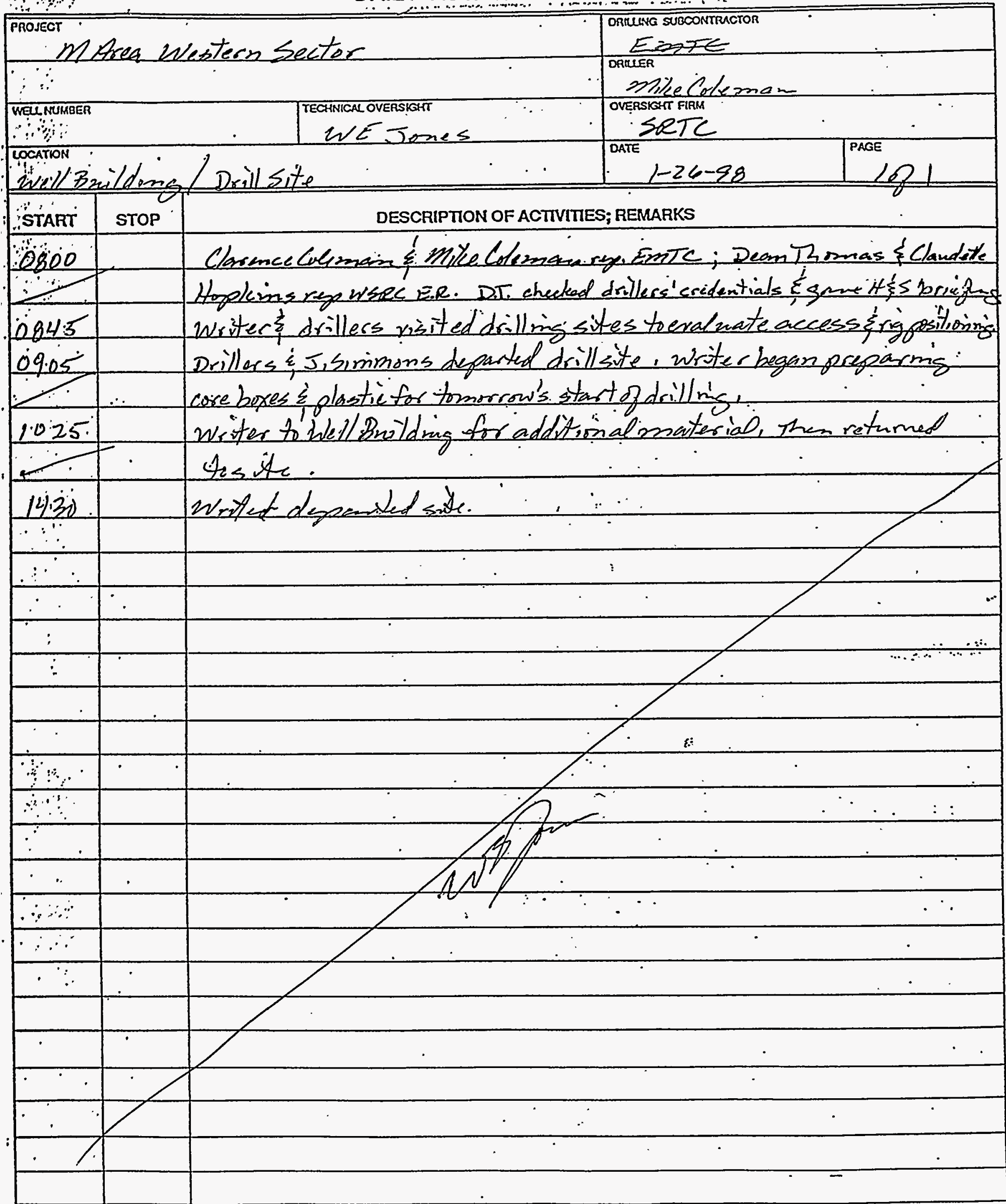

TECHNICAL OVERSIGHT SIGNATURE 
DAILY ACTIVITIES REPORT

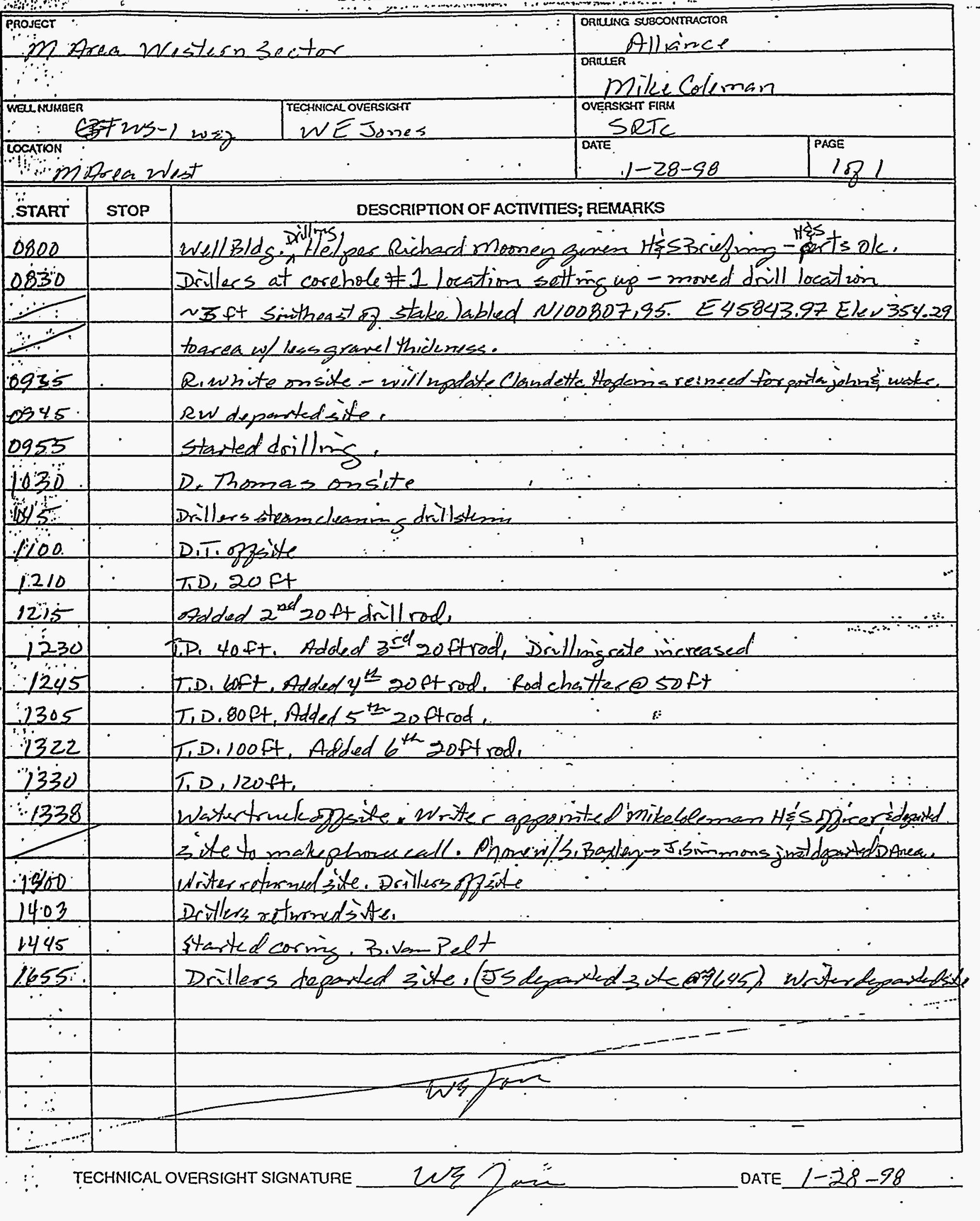


DAILY Y ACTIVITIES REPORT.

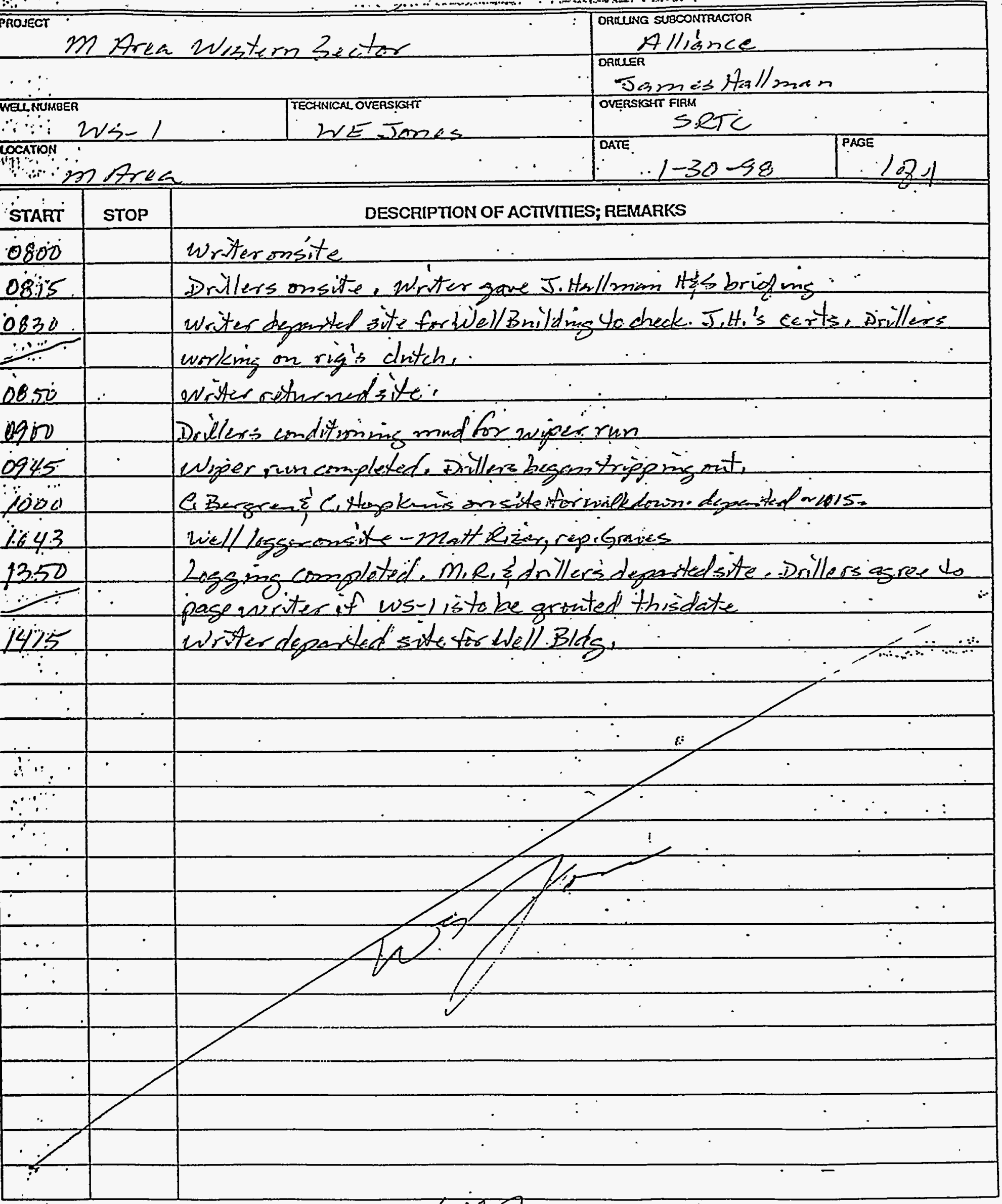

TECHNICAL OVERSIGHT SIGNATURE

WI ja

DATE $7-30-58$ 


\section{PROJECT}

Mrea evestern sector

$\therefore$

WELL NUMBER

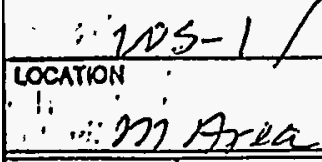

\begin{tabular}{|l|l|}
\hline START & STOP \\
\hline OASCO & \\
\hline 0832 & \\
\hline 0840 & \\
\hline 0850 & \\
\hline 0920 & \\
\hline
\end{tabular}

1030

1100

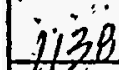

1248

1330

134

1350

1408

1430

1448

1500.

1510

.1550
TECHNICAL OVERSIGH

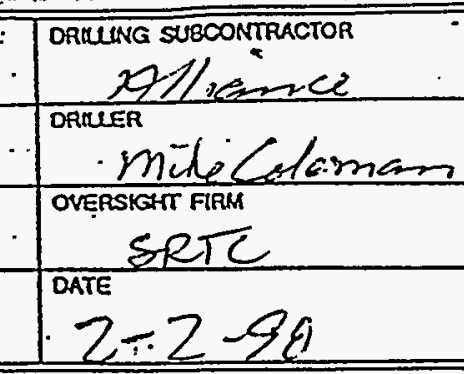

DESCRIPTION OF ACTIVITIES; REMAR̈KS.

Mrite ansits dnylessensiter

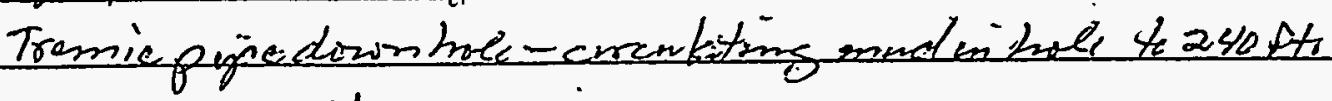

D. Themes on inte,

DT, departed site.

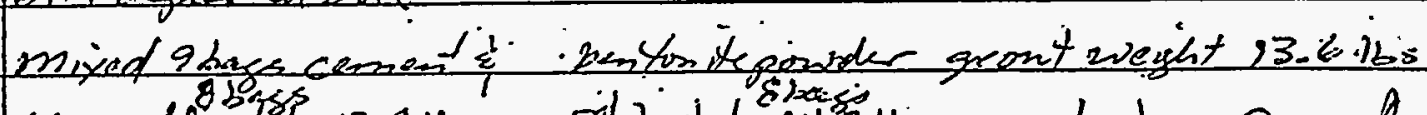

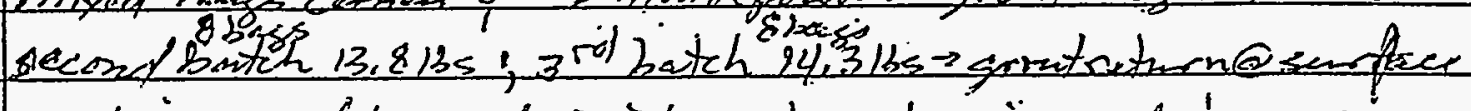

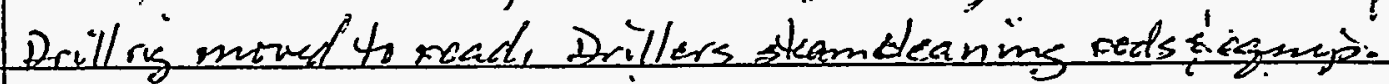

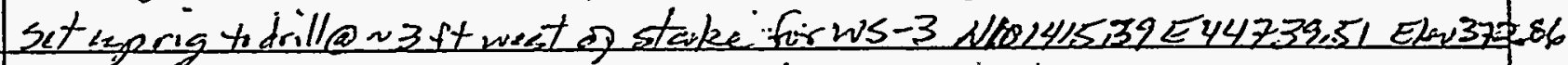

Begandrilling $2 \times 5-3$

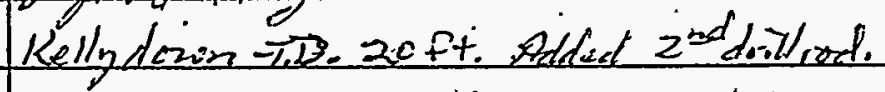

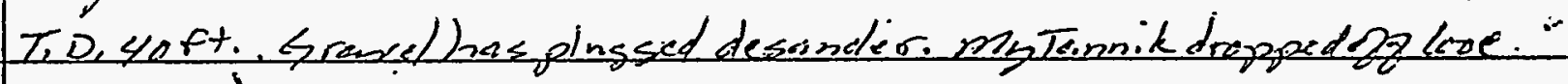

(cothonse)

trded 3 ret drillinel.

T.D, leo ft. Aolded $y^{\text {th }}$ rad.

T.D. $80 \mathrm{ft}$, Lightrain bezan. 5 "th rodaddeds:

T.D. 100 ft. $6^{\text {th }}$ rodadded.

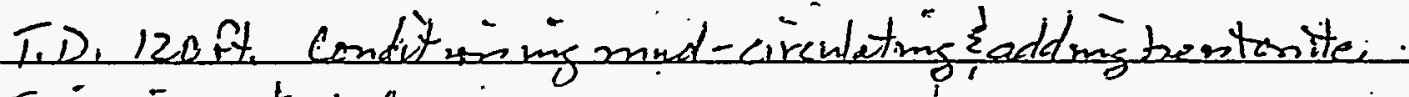

Tripengontoghole:

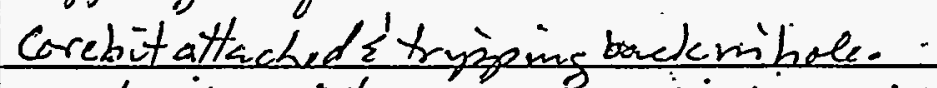

bertters in writier deppoized inte 
$\operatorname{OS} R 30.2$ (Rev 12.89)

DAILY ACTIVITIES REPORT



TECHNICAL OVERSIGHT SIGNATURE DATE $2-6-98$ 
$0 S i 230.2$ (ReV 12.89)

DAILY ACTIVITIES REPORT

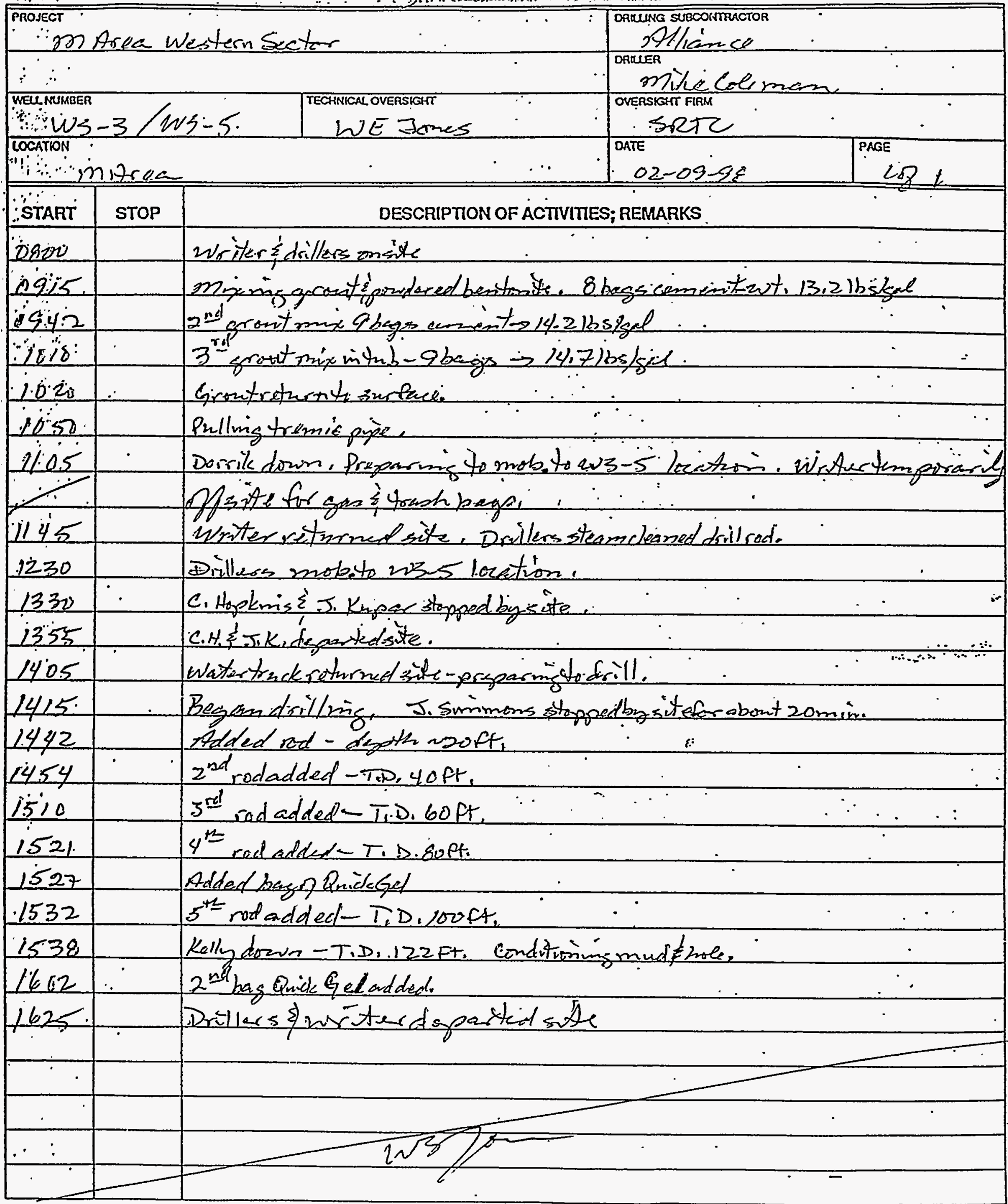

TECHNICAL OVERSIGHT SIGNATURE $2 \sqrt{5}$ DATE $2-9-98$ 


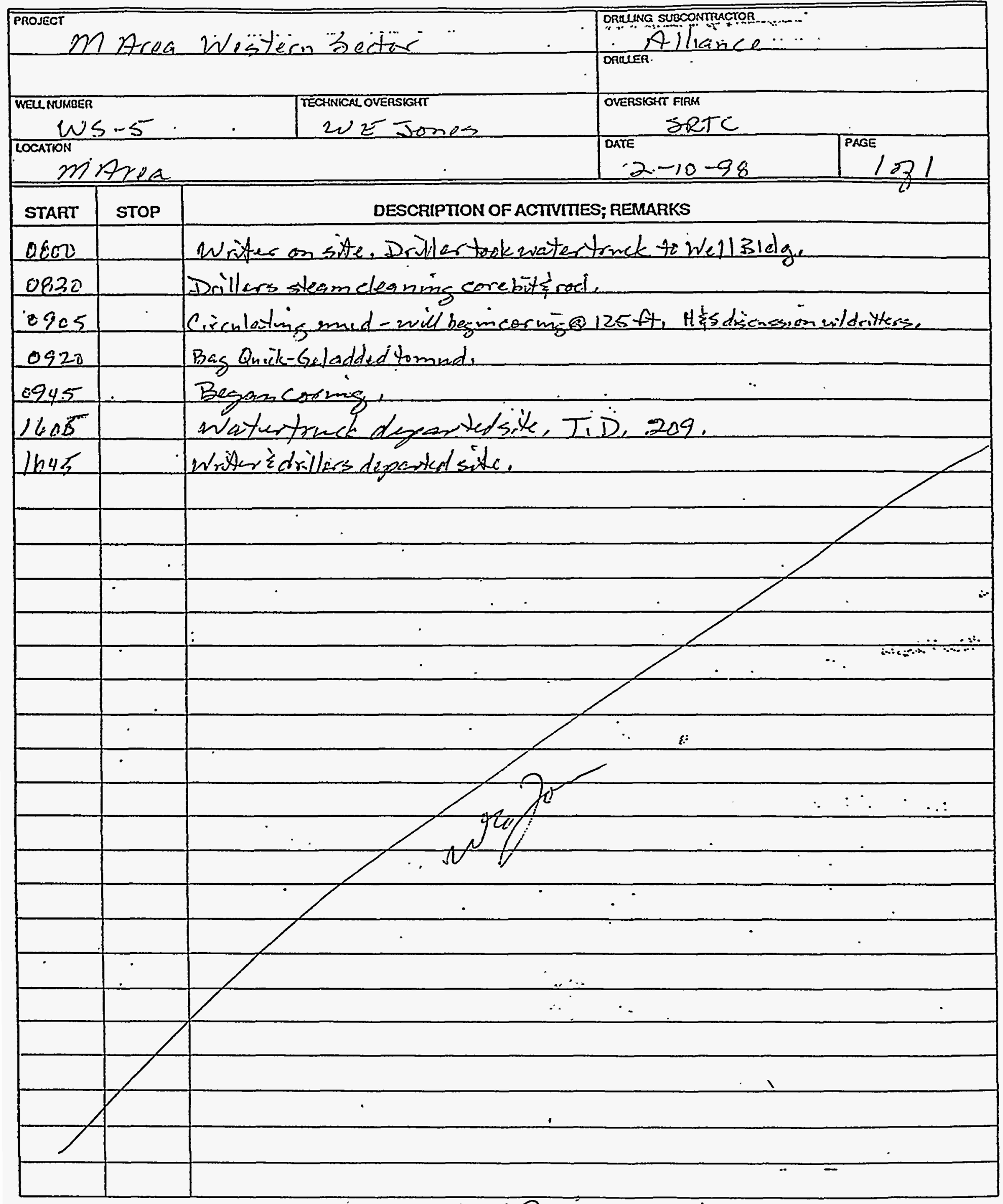

TECHNICAL OVERSIGHT SIGNATURE. 


\section{DAILY ACTIVITIES REPORT}

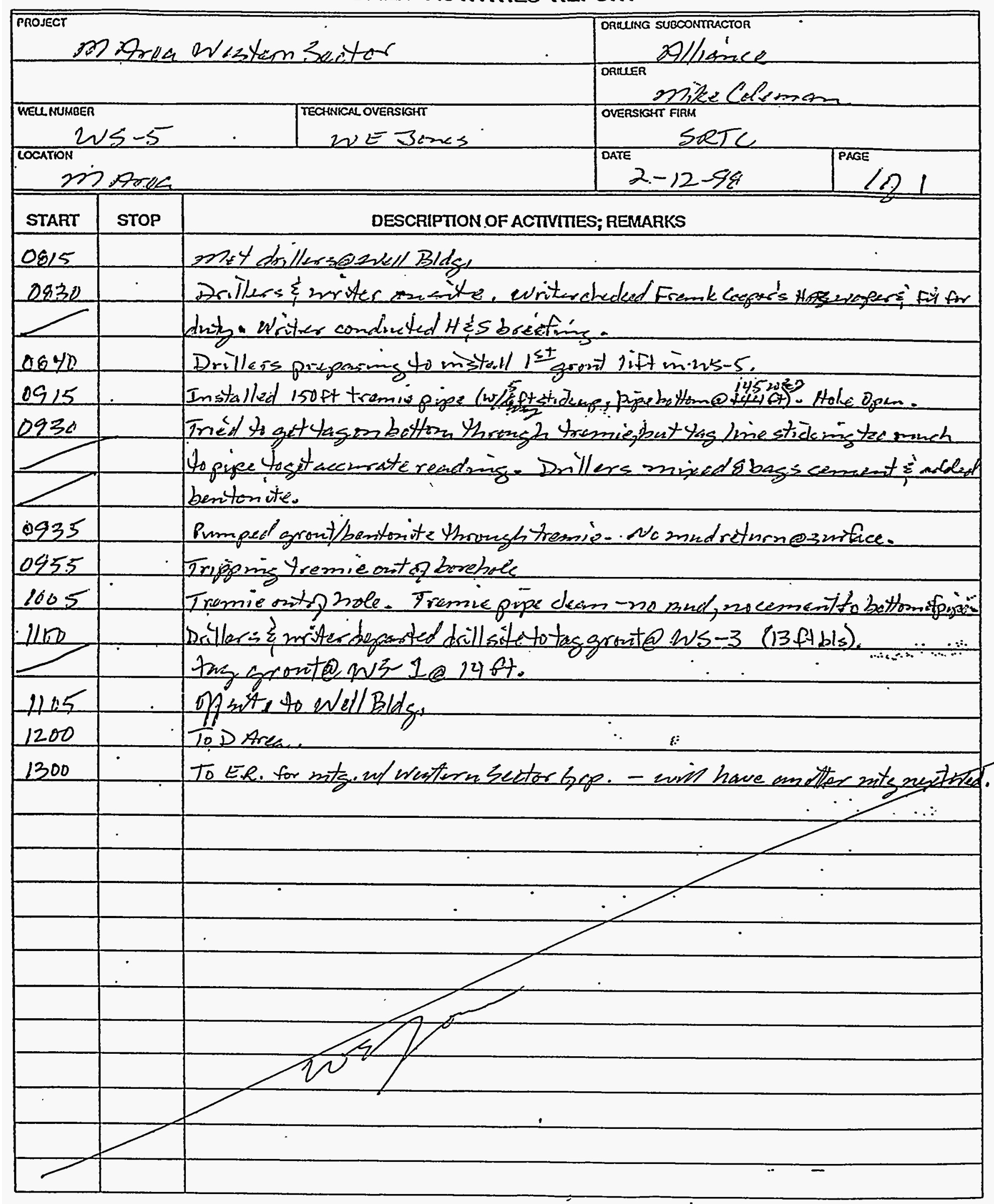

TECHNICAL OVERSIGHT SIGNATURE

幽2

DATE $2-12-98$ 


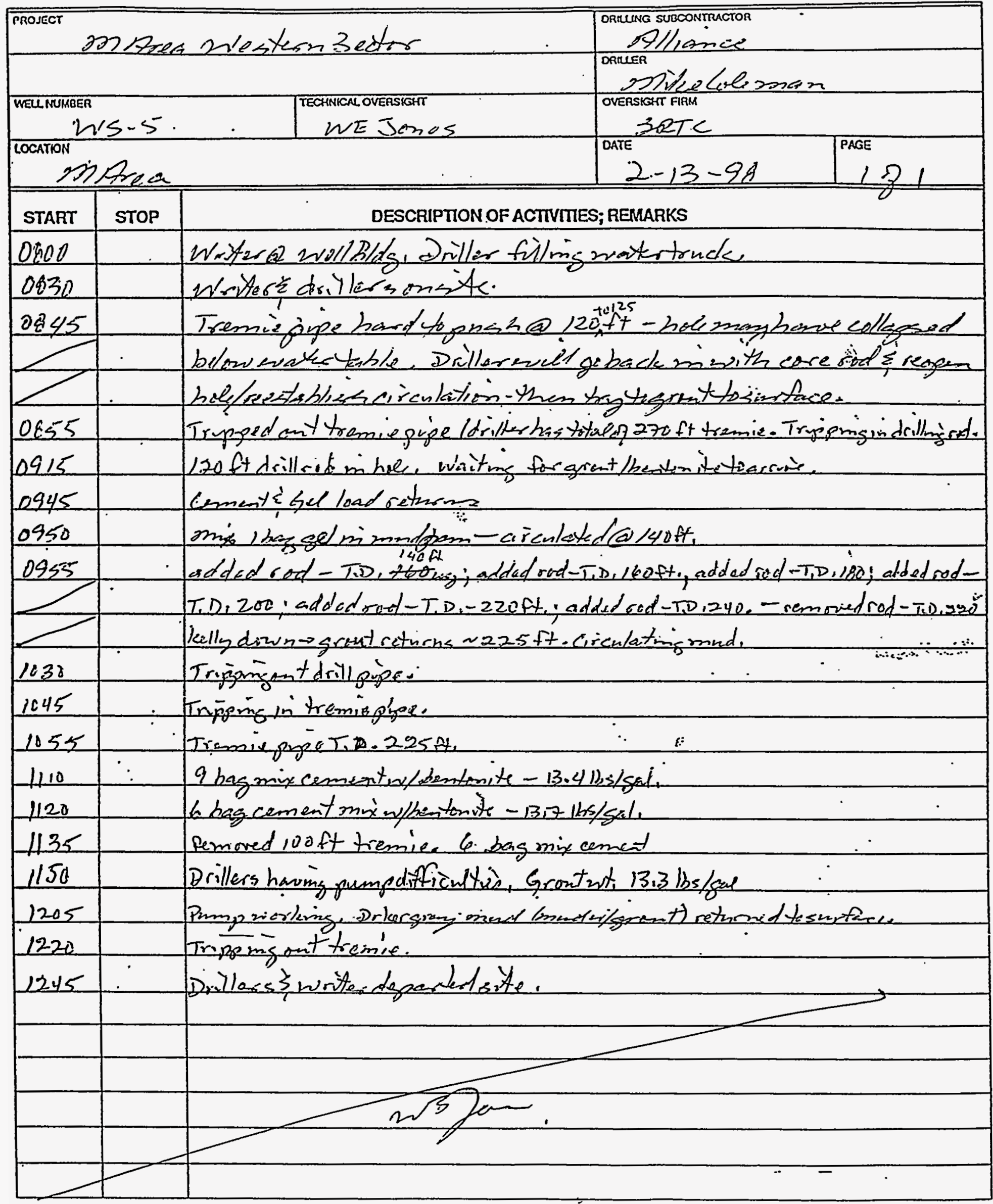

TECHNICAL OVERSIGHT SIGNATURE NUS DATE $2-13-90$ 


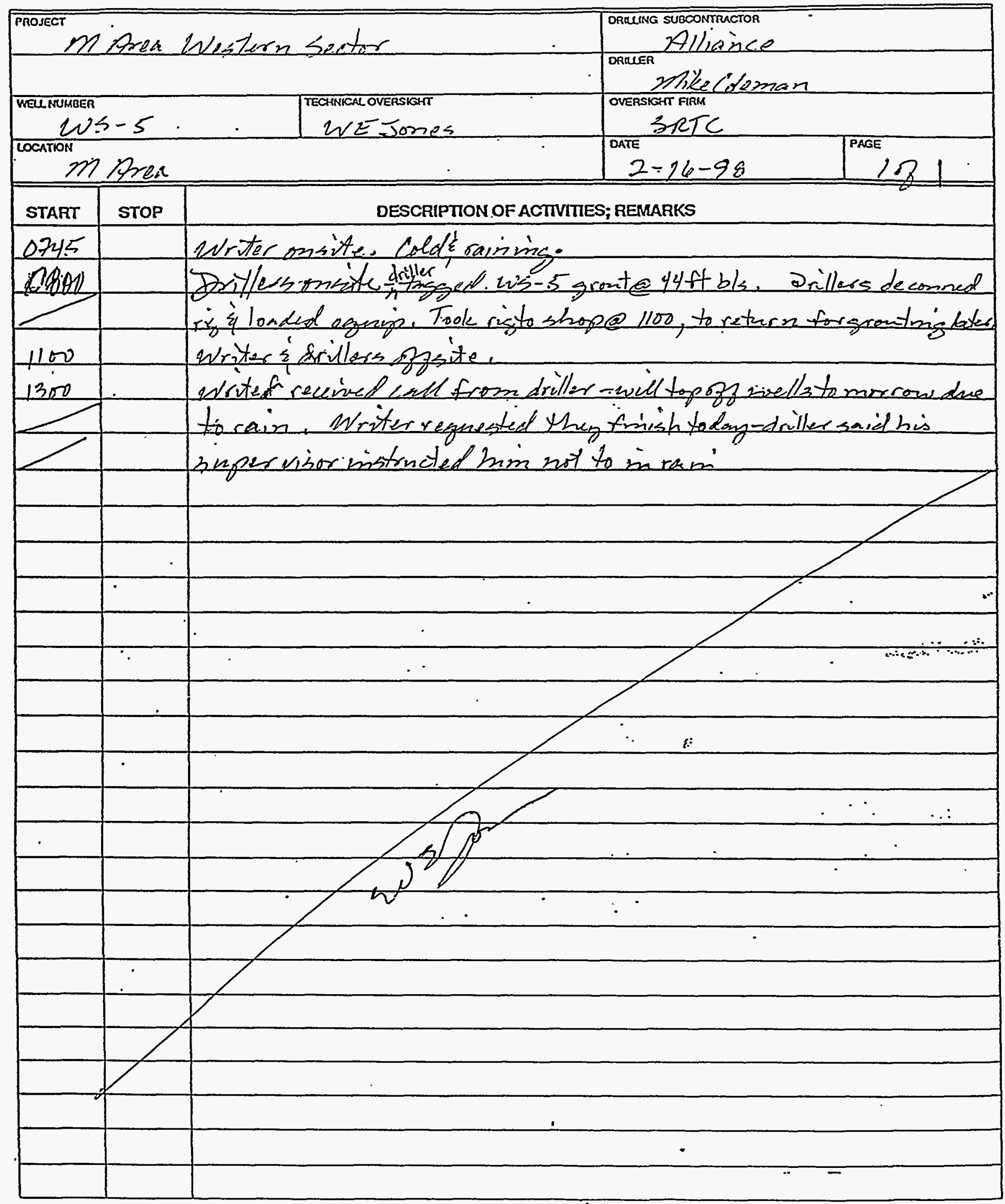

TECHNICAL OVERSIGHT SIGNATURE Wh. Jow 


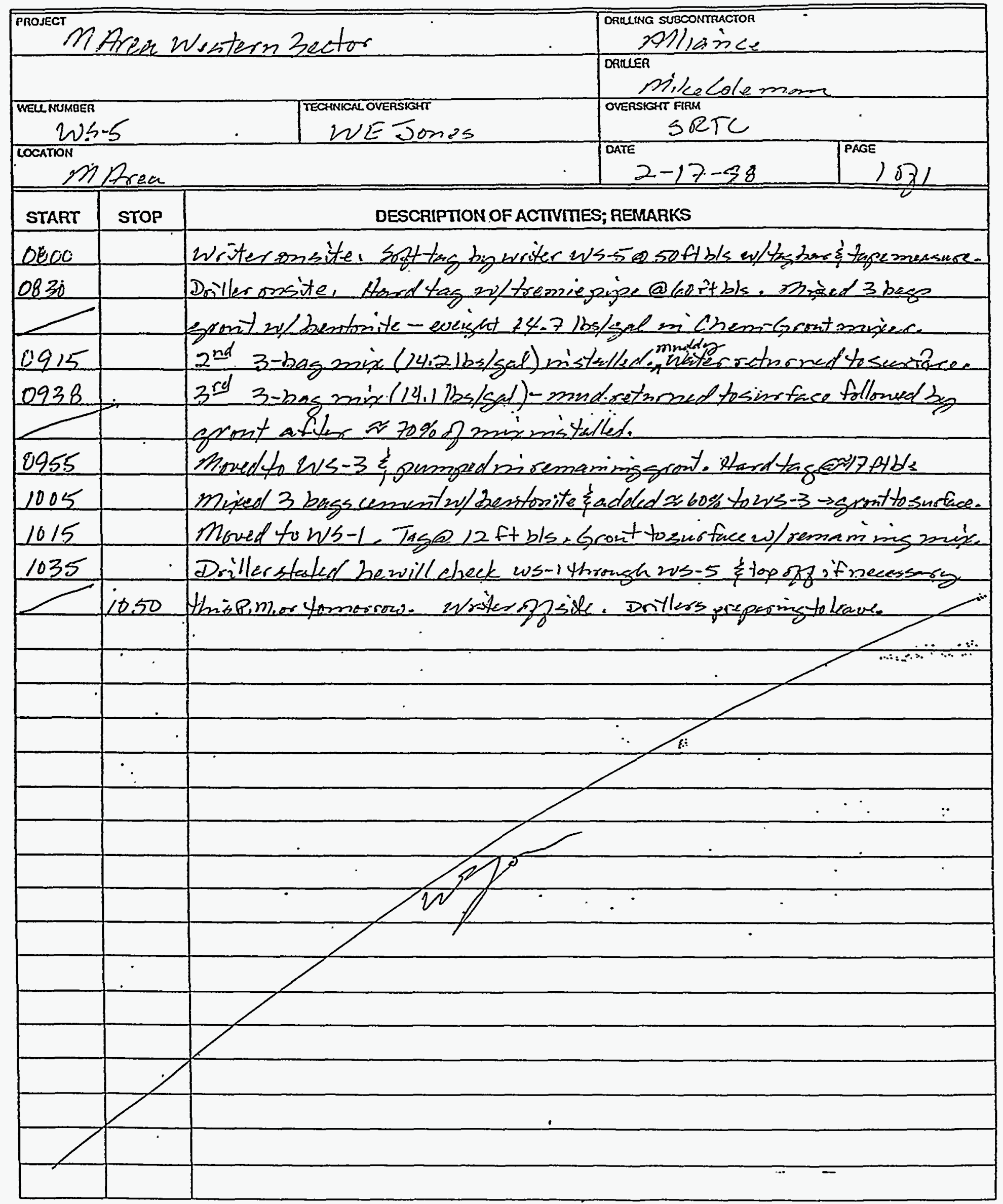

TECHNICAL OVERSIGHT SIGNATURE 117 pous

DATE $2-17-98$ 


\section{APPENDIX B}

\section{Field Geologic Logs}




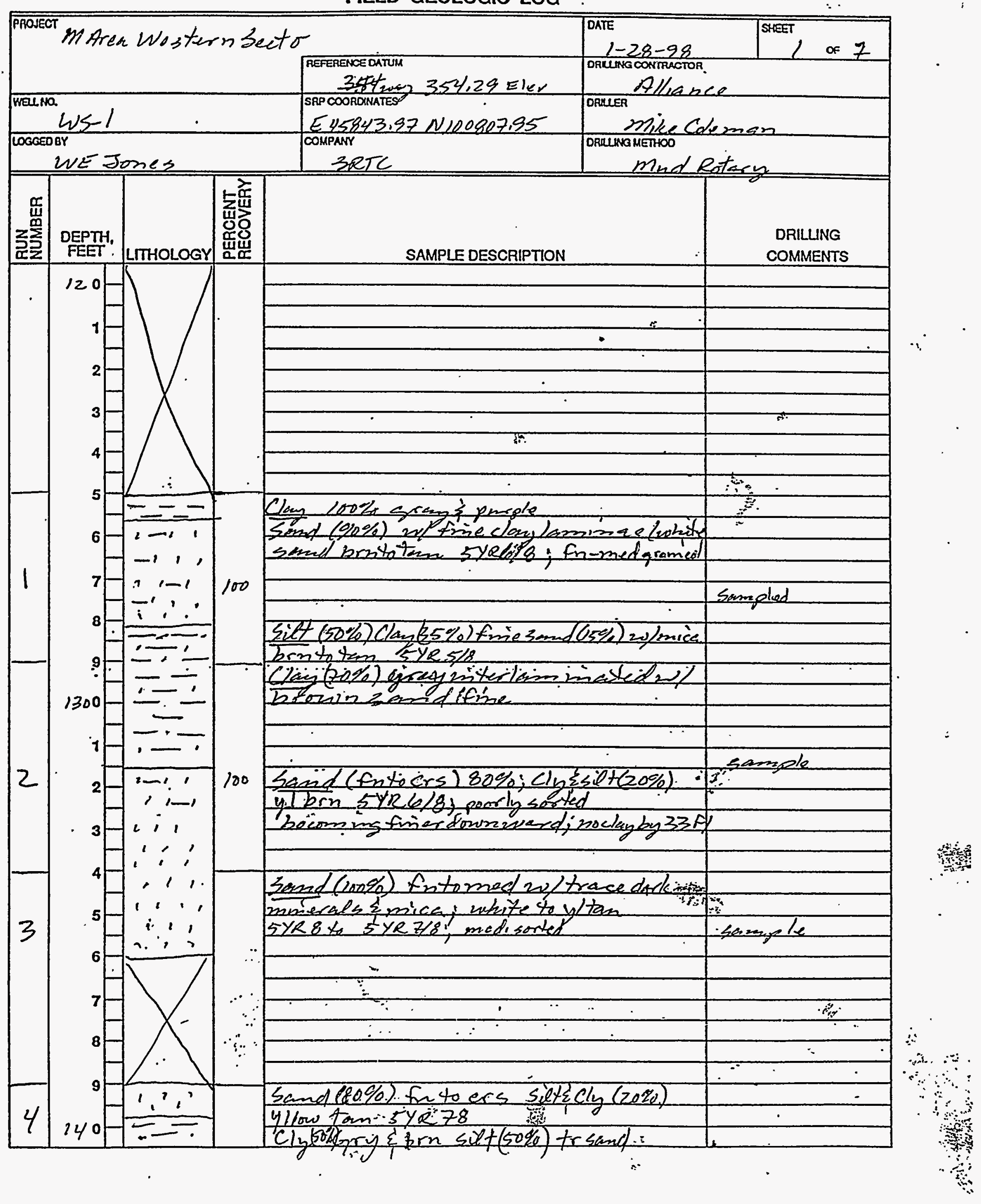


FIELD GEOLOGIC LOG

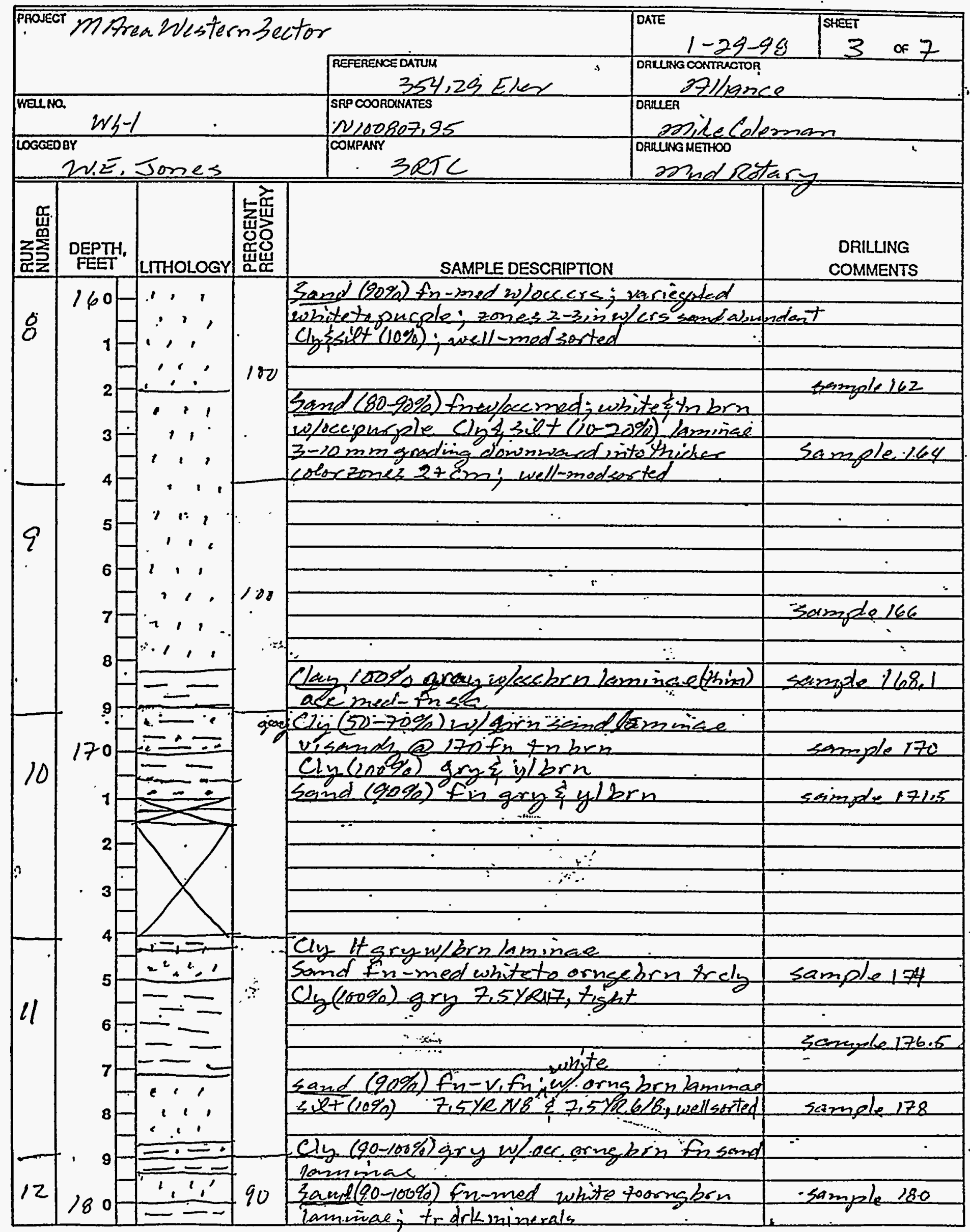




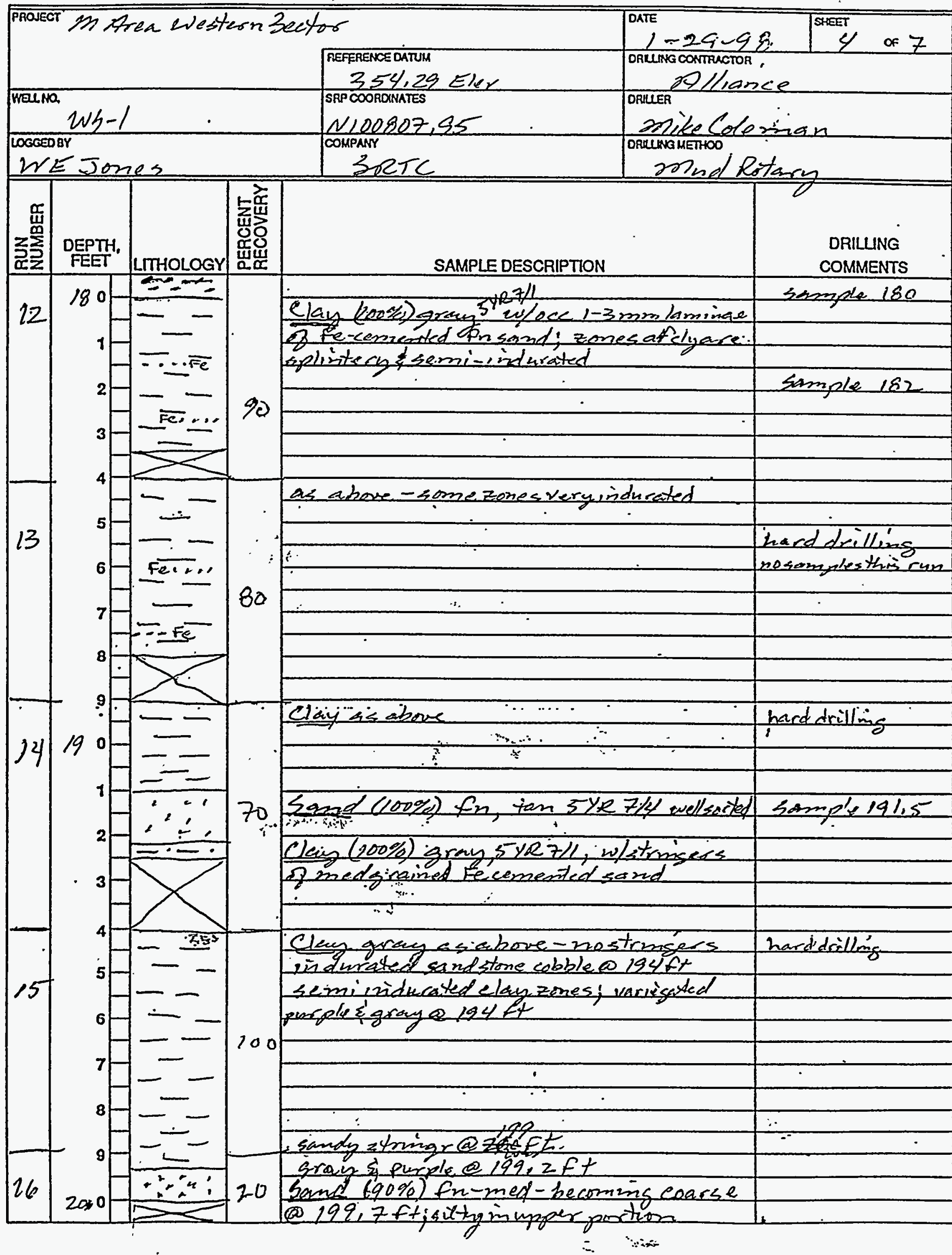




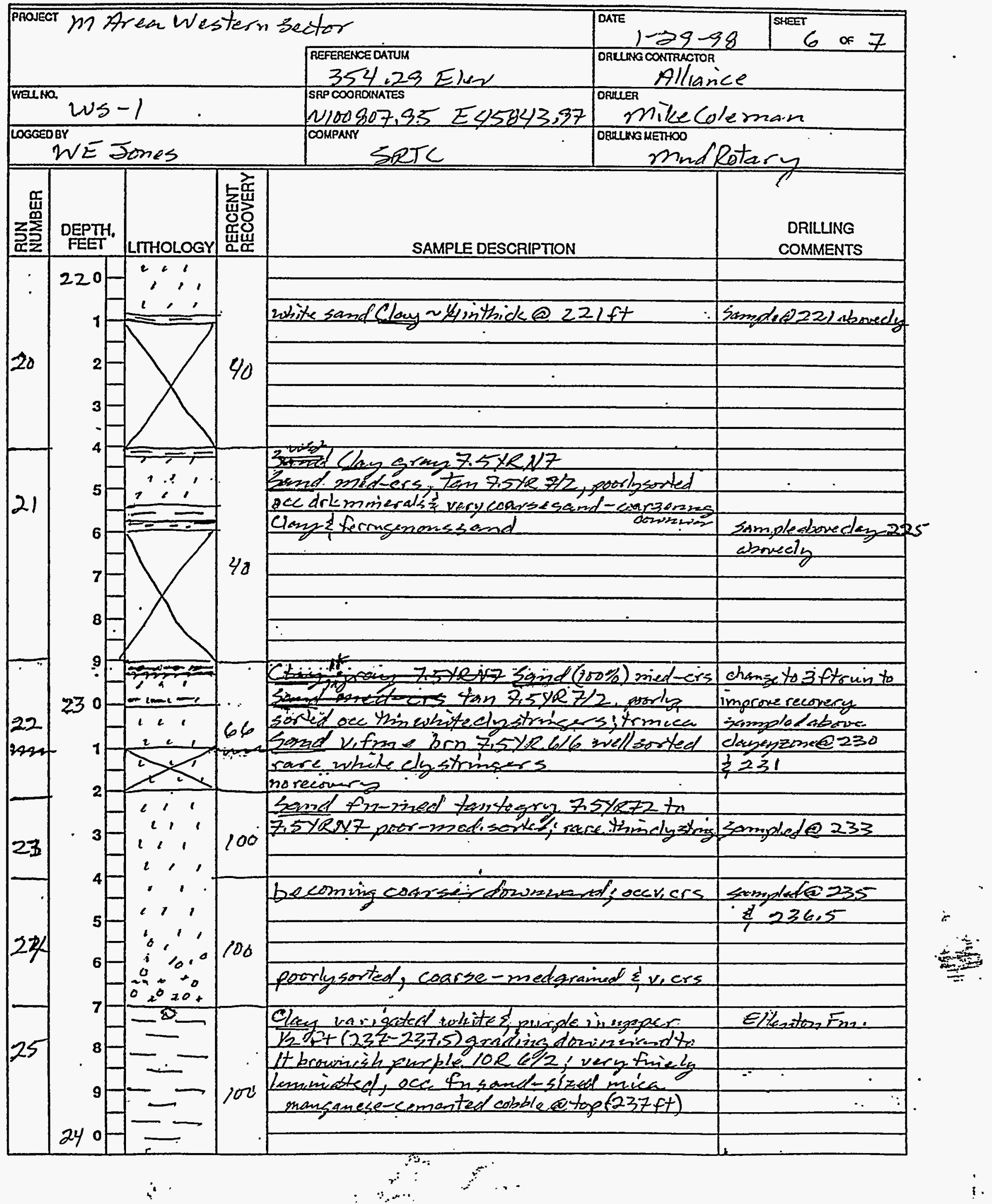




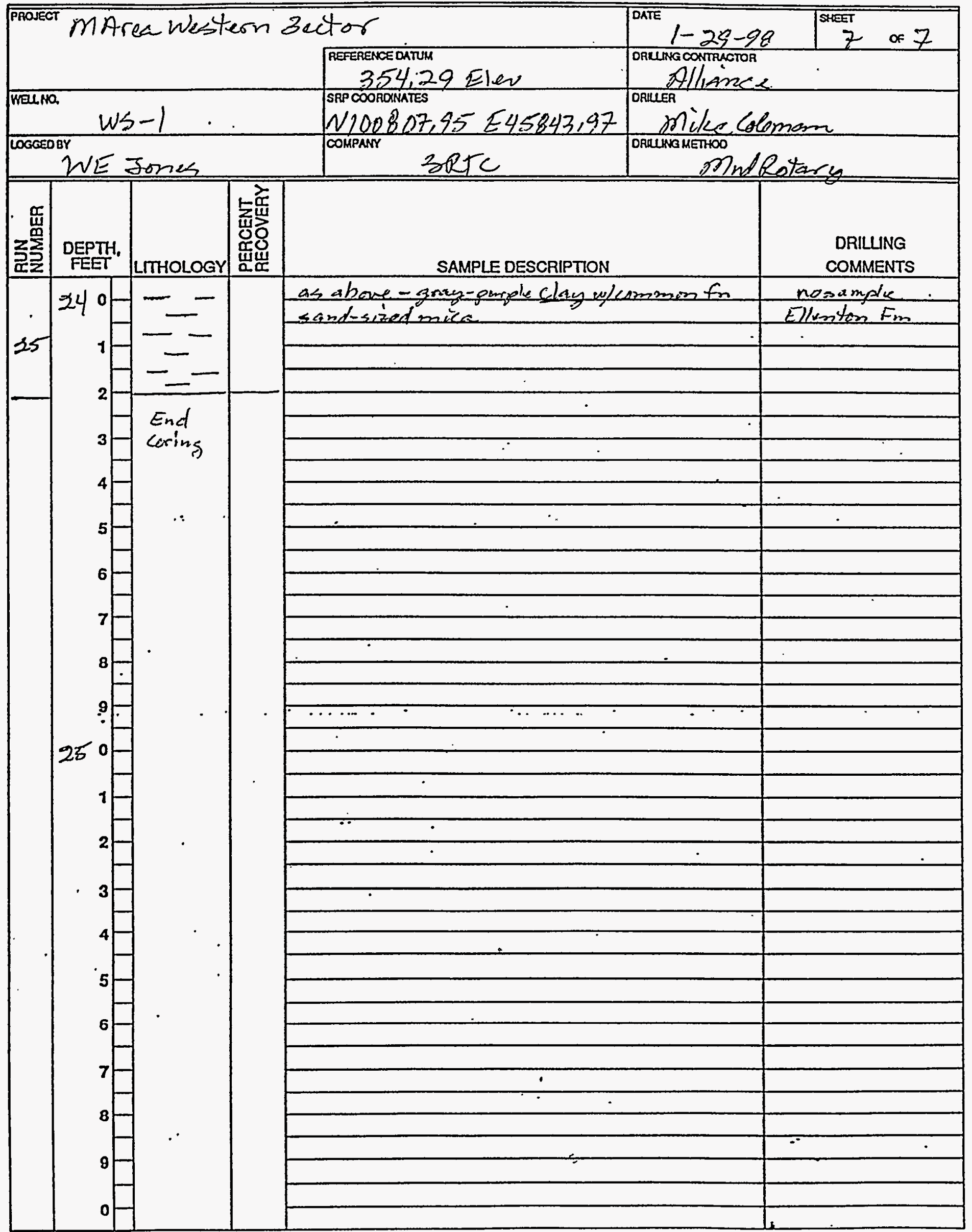









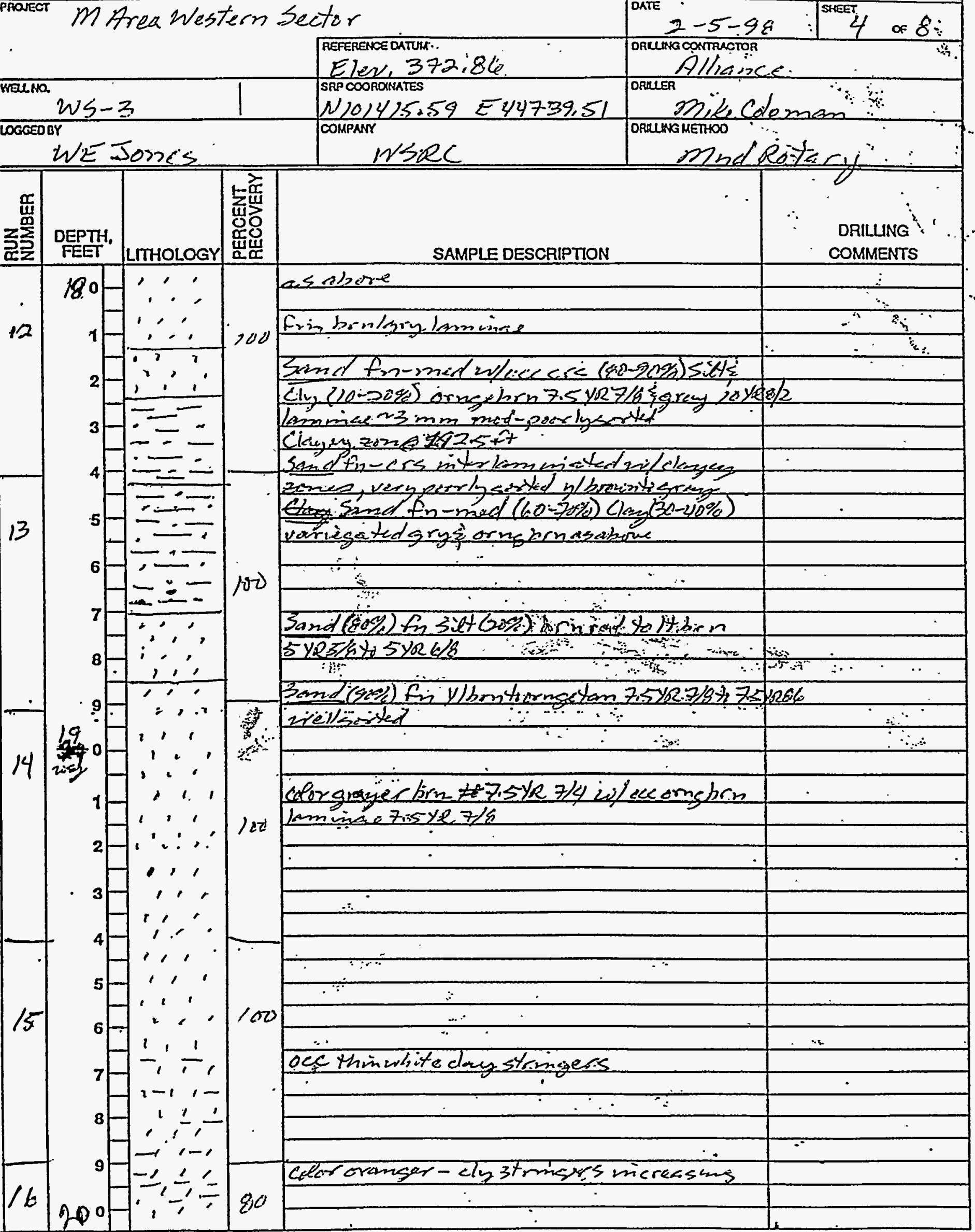




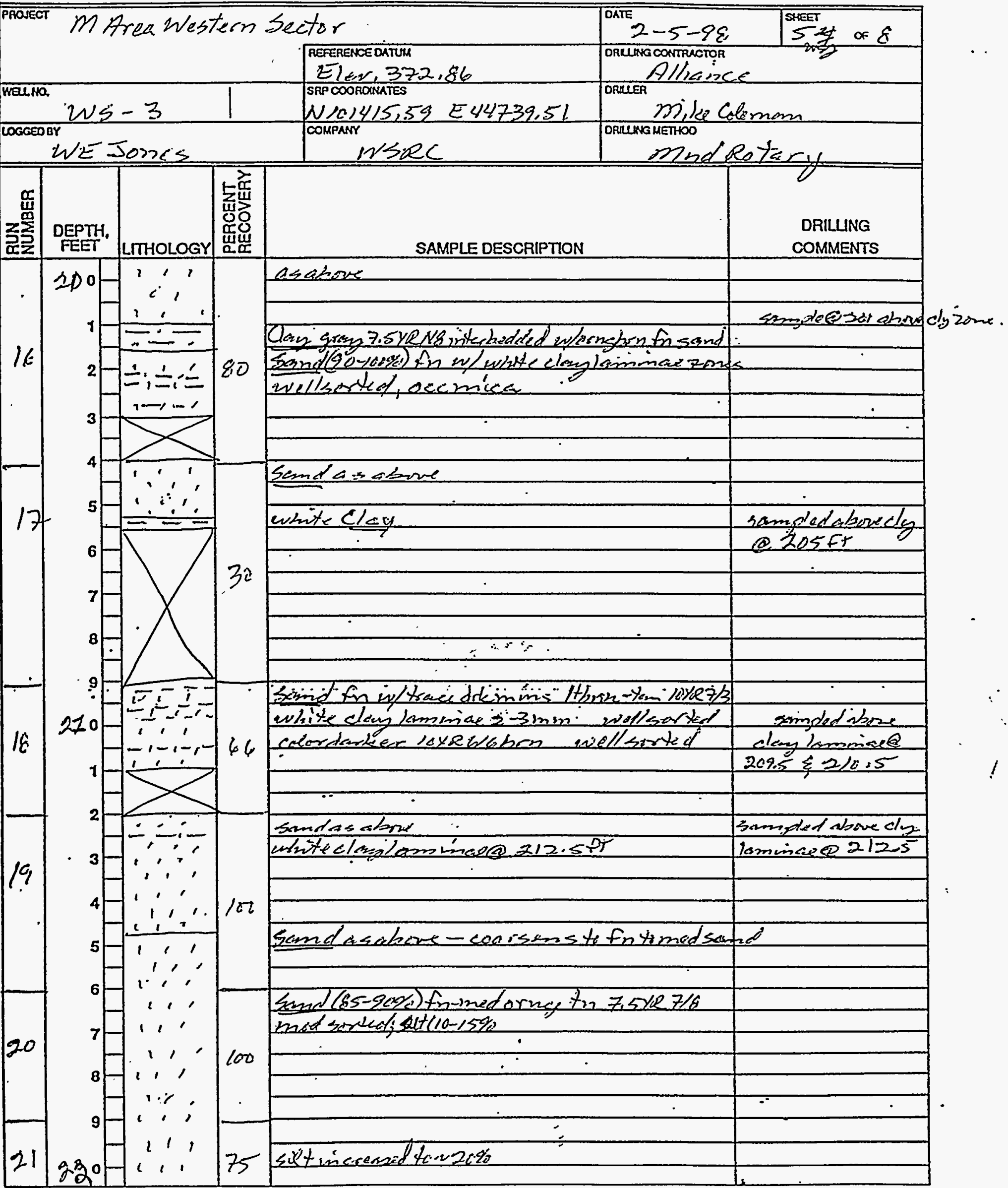




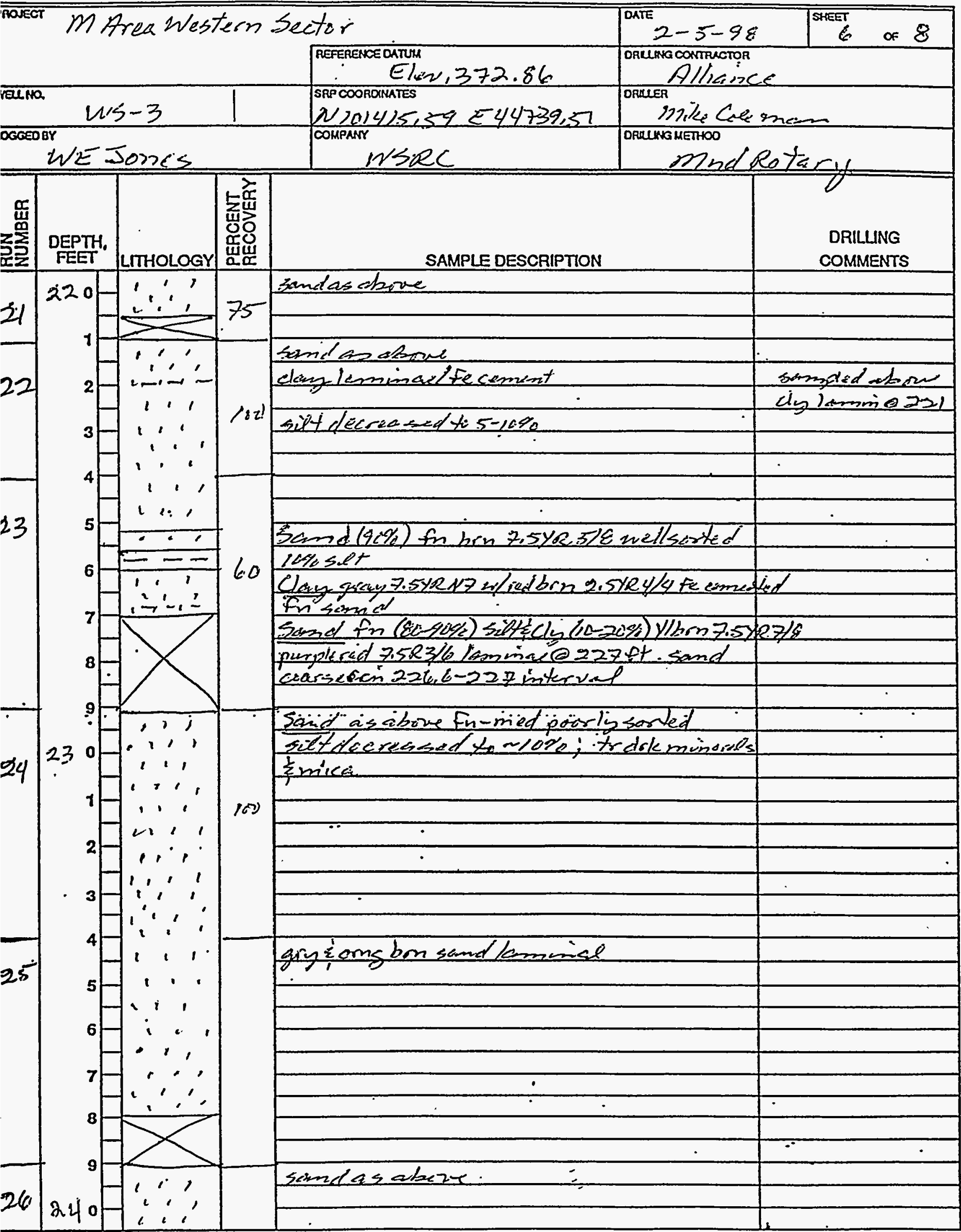




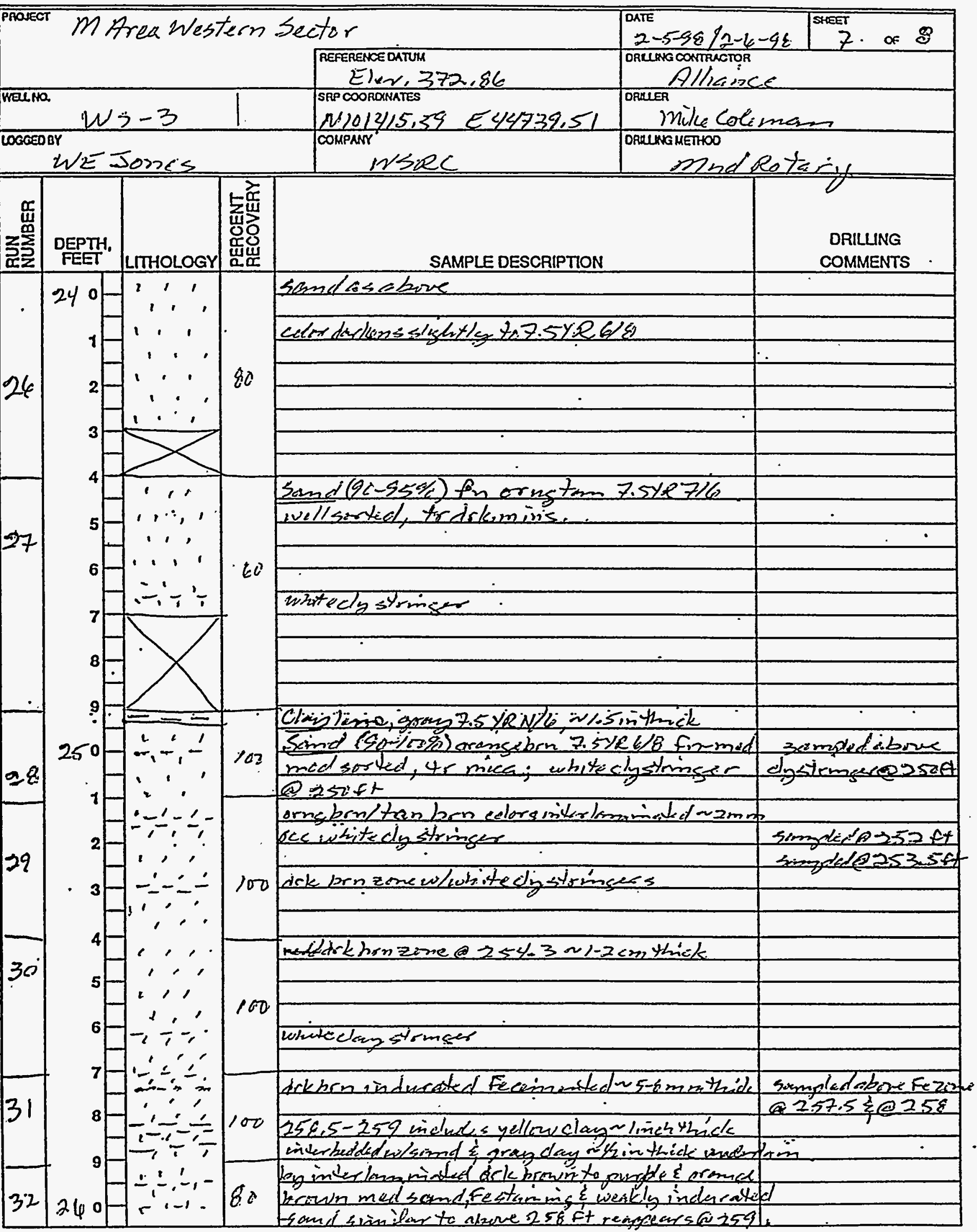




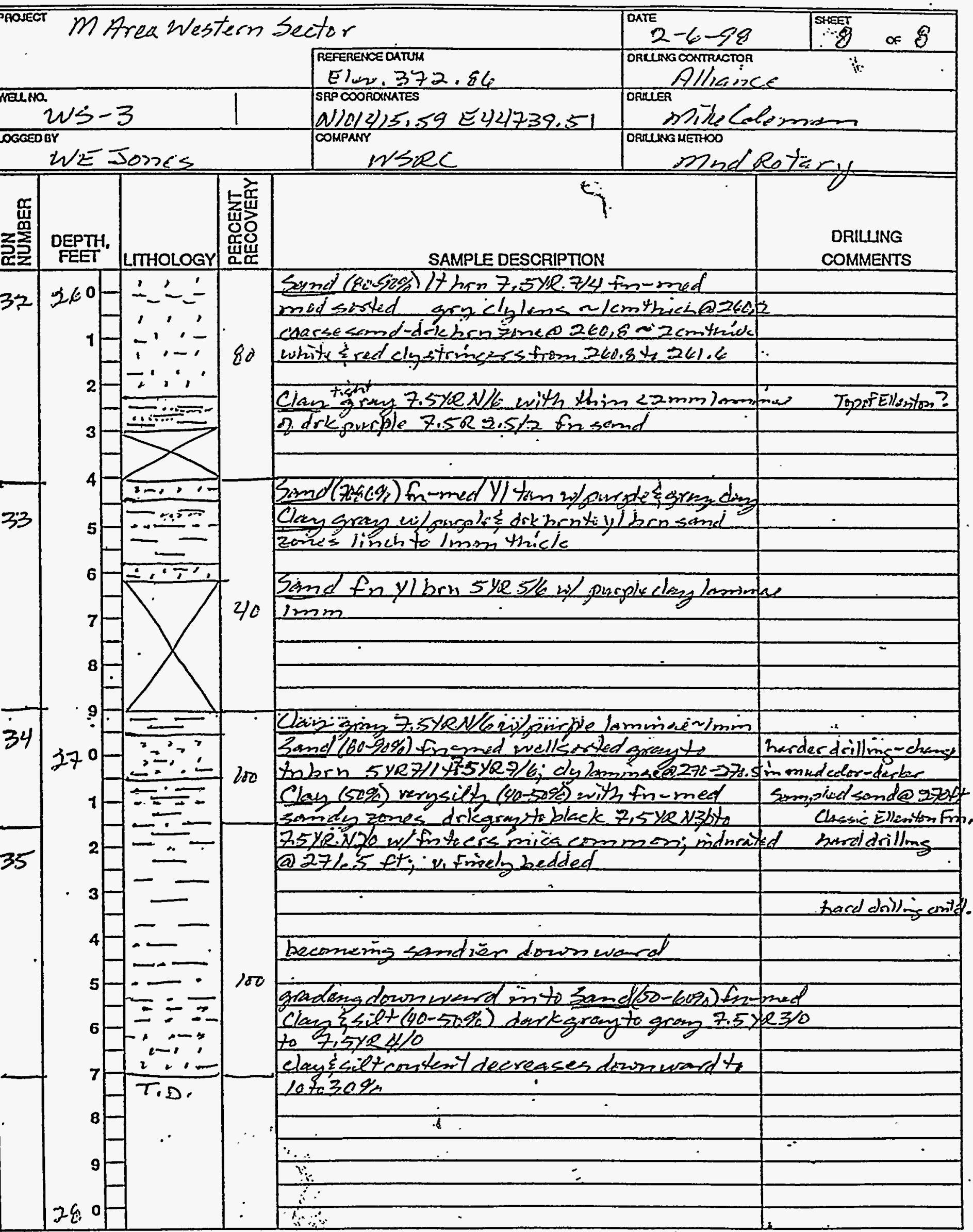




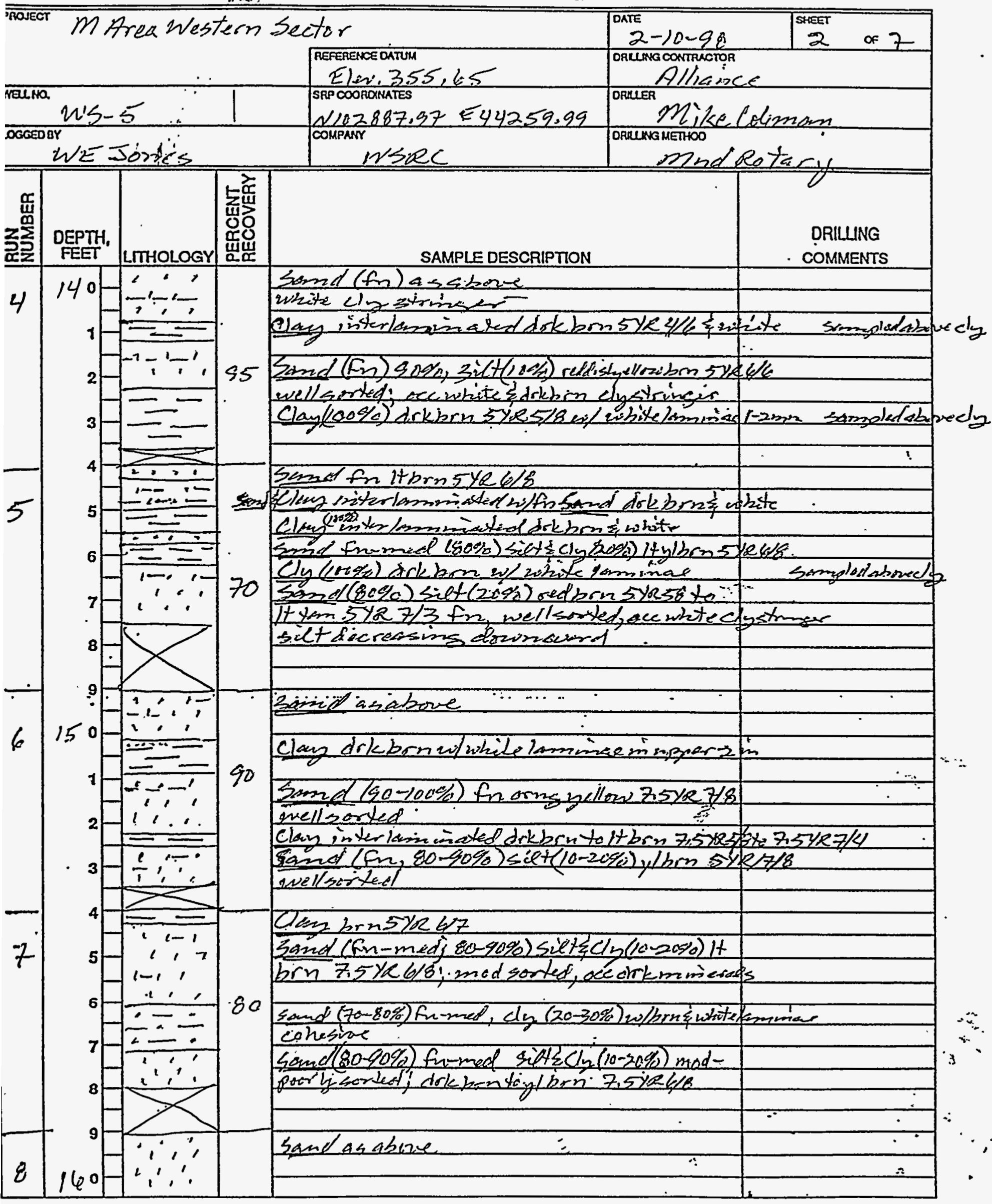




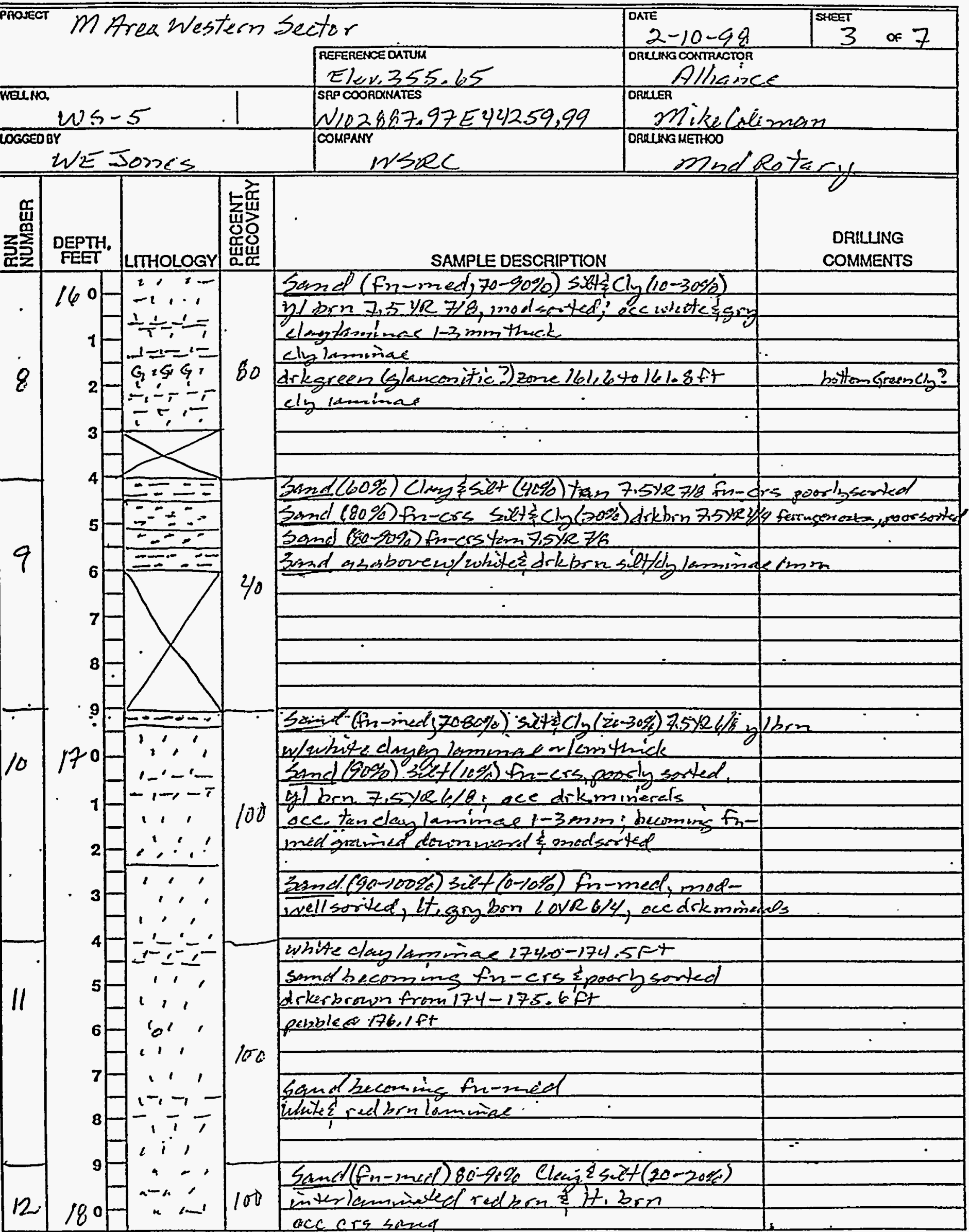




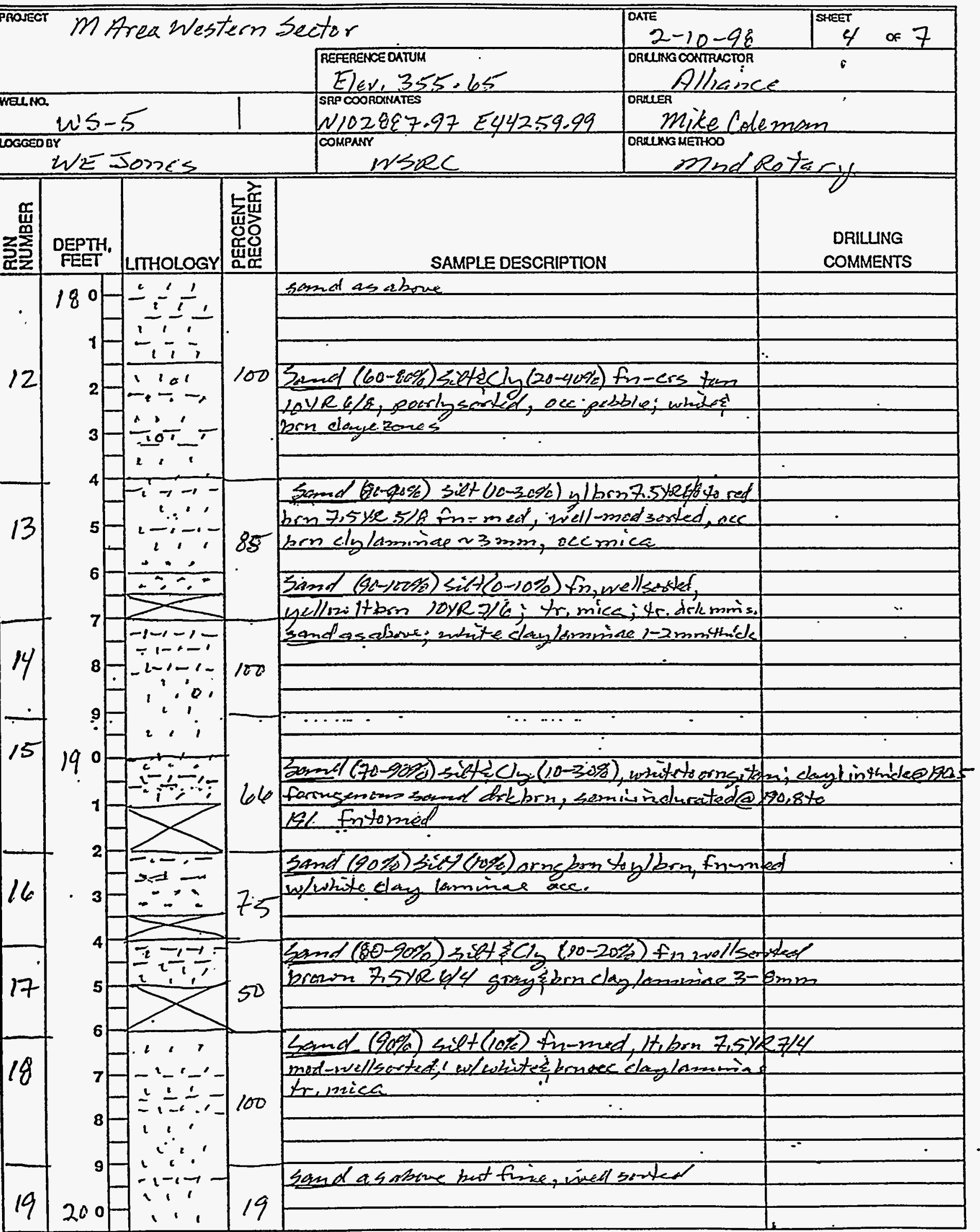




\section{APPENDIX C}

\section{Geophysical Logs}








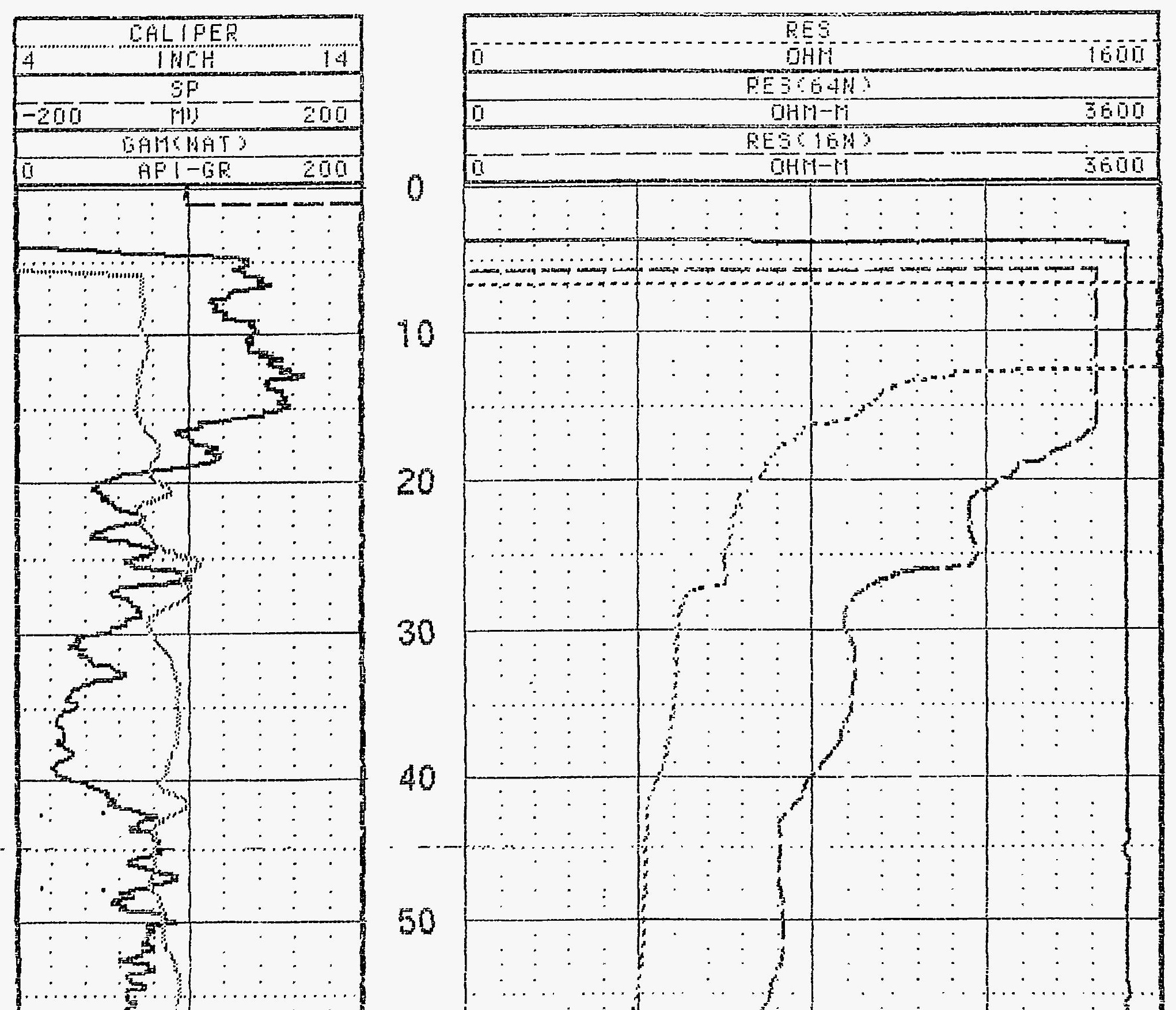







\section{GRAVES \\ ENVIRONMENTAL \& GEOTECHNICAL SERVICES}

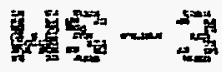

COHPH旅

HELL

LOCATIOH/FIELD : HESTEHT SECTOR

COUHTY

STATE

ECTIOH

DATE

DEPTH DFILLEF

LOG BOTTOM

LOG TOP

CASING DFILLER: :-

CAFEHG THPE :-

CASIHG THICHHES: -

EIT SIZE : 5

AFGFIETIC DECL. : -

MATHIX DENSITY : -

FLUYD DENSITY : -

HEUTRON HATRIX : -

ALLIAHCE

$4 \mathrm{~S}-3$

AKEN

58

Q. $.9 B$ FH
G2/06,96 FEHFANENT DATUH :

ELEV. PEFH, DATLYA: -

277.30 LOG MEASURES FFOH: GE

DRL MEASUREO FROM:

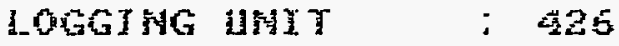

FIELD OFFICE

RECORBES H:

: IACKSOH, $\mathrm{S}, \mathrm{C}$

: NIZIER

BOFEAOLE FUID : WUISHZE FILE : FROCES

FW TEMPERATUAE :

MATMIX DELTH T : -

FLUTD DELTA $T$ : --
ELEWATIOHS

$\begin{array}{ll}\text { KB } & : \\ \mathrm{DF} & : \\ \mathrm{GL} & :-\end{array}$

TUPE : 9 PSA

$\log : 5$

FIOT: 4444

THEESH : 5 GGGG

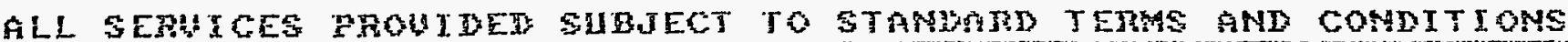




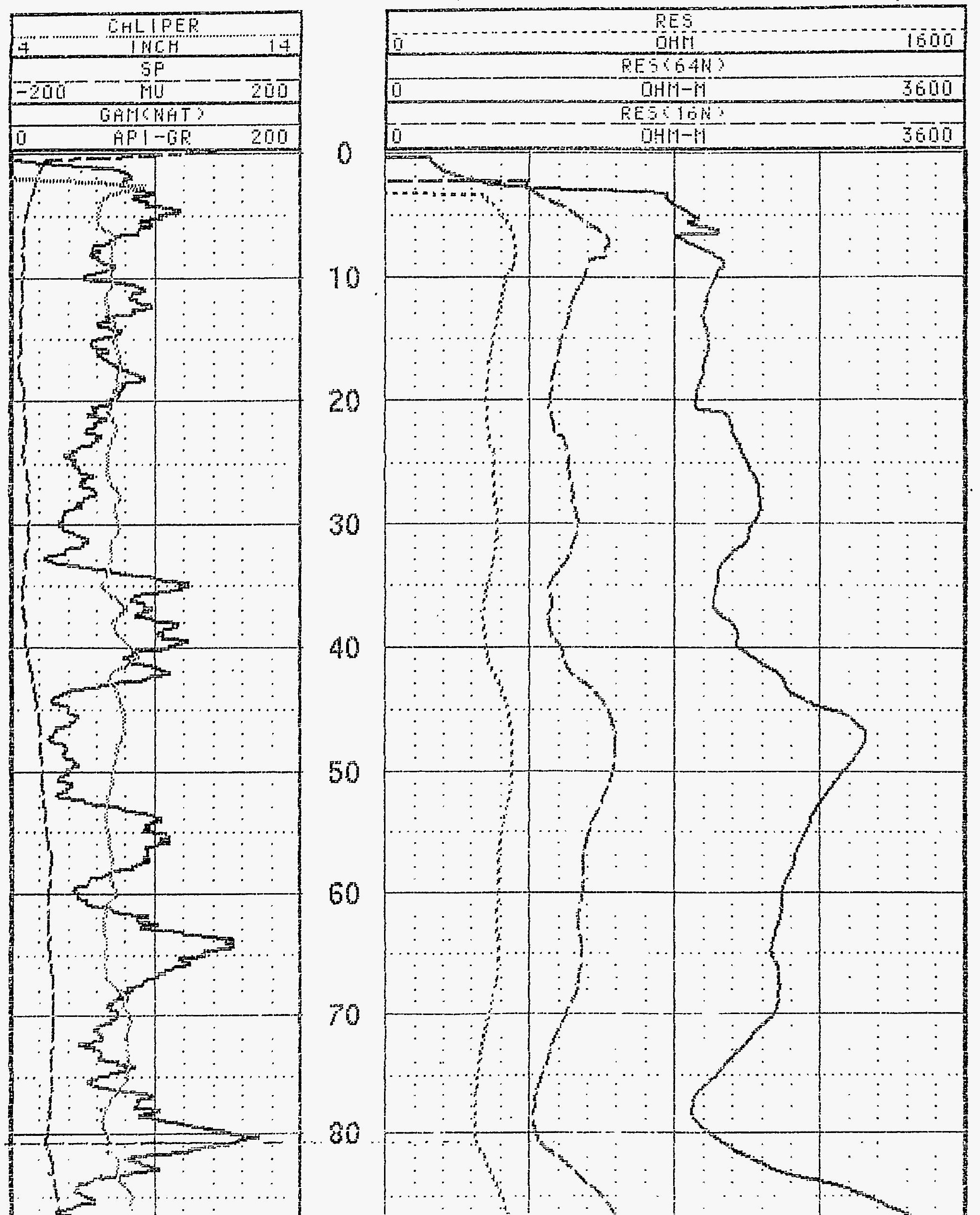




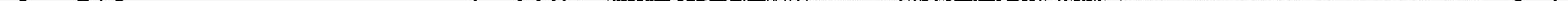




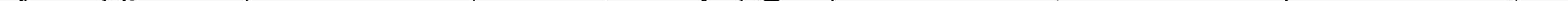


Data Summary Report: M-Area

Western Sector Remediation Project (U)
WSRC-TR-98-00089

April 1998

\section{APPENDIX D}

Soil Sampling Field Log and Duplicate Analyses Comparison Summary 
Peote Time smple ID Depth Descuiptionte

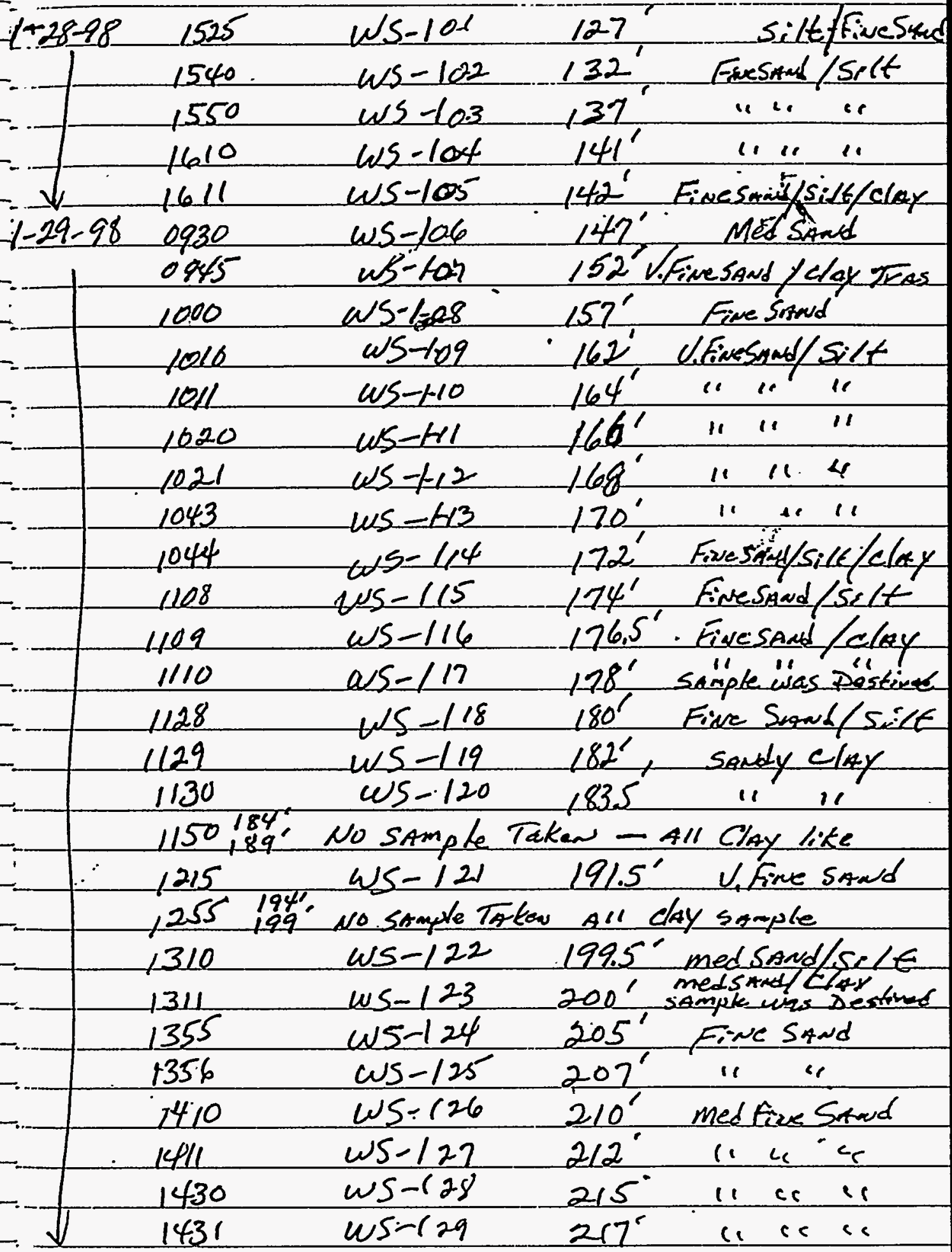



Pon

$$
\begin{aligned}
& , 1,1, \\
& \text {; }
\end{aligned}
$$

Pस्ts DNy 9DN

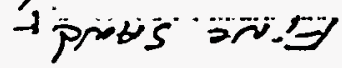
prissañ trop/praspan

$$
\text { , , , }
$$

pNtes añy SR.td? iss
गह-1 $5 \varepsilon$ $\varepsilon \varepsilon$ iष्ट br iste $\pi$ $.3 / 2$ yxdoc
(E.) $=5 m$ $7 \varepsilon-1-5 m$ $s \varepsilon-i-s m$ $\not \varepsilon-1=5 \mathrm{~s}$ $\varepsilon \bar{\varepsilon}-1-s m$ $\because \varepsilon-1-\operatorname{sm}$ $\pi \varepsilon-\pi-s m$ o $\varepsilon-1-S M$ $\sigma$ I aydurs $10.57-1$ tits |ES| SEST a०si $05 x 1$ btiti - BSbz-

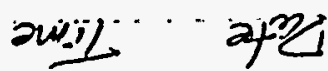




$$
\text { -. } 39
$$

Date Time... Sample Ed Depth Description

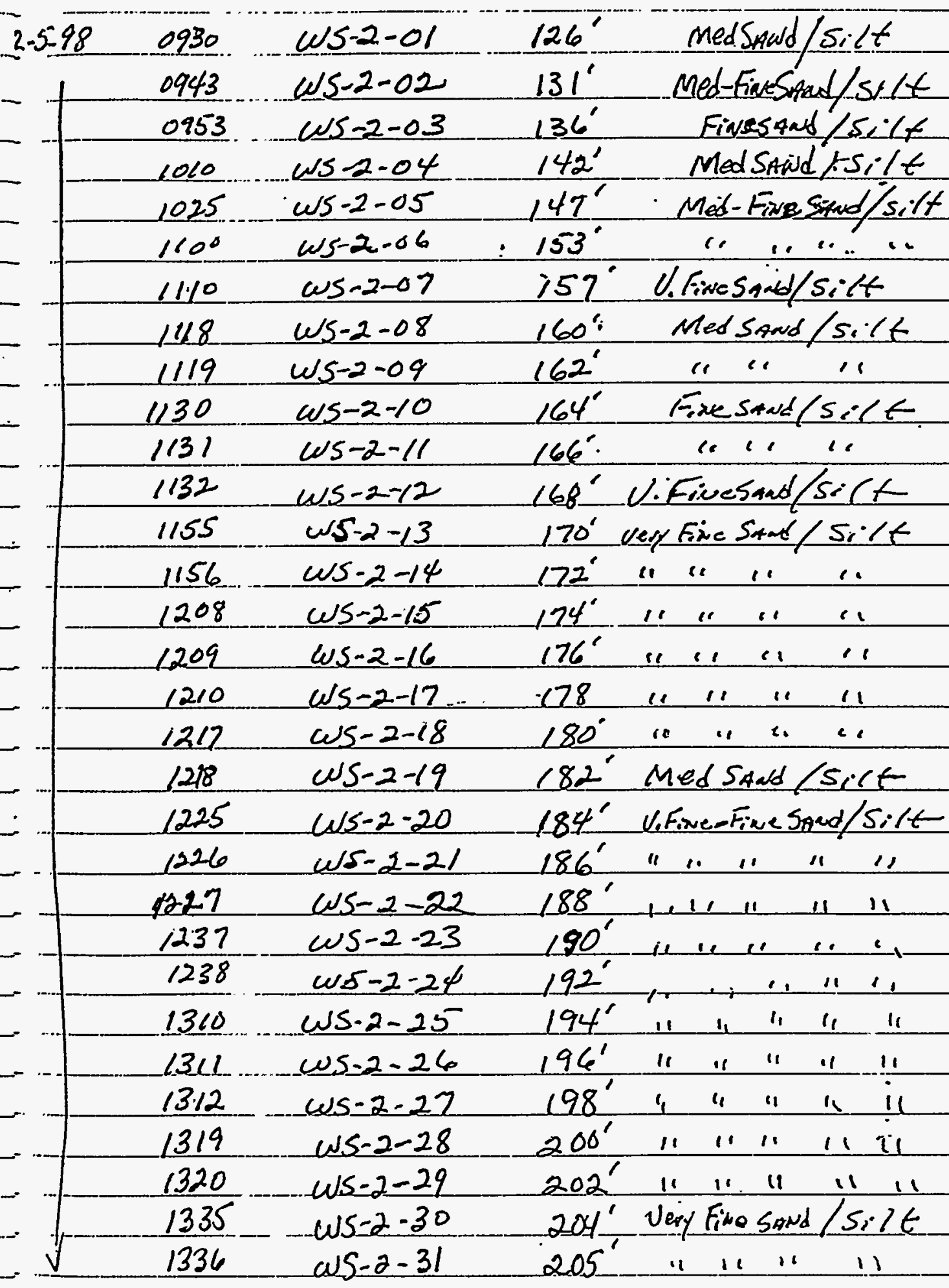


41

Date Time Sample ID Depth Descorptriv

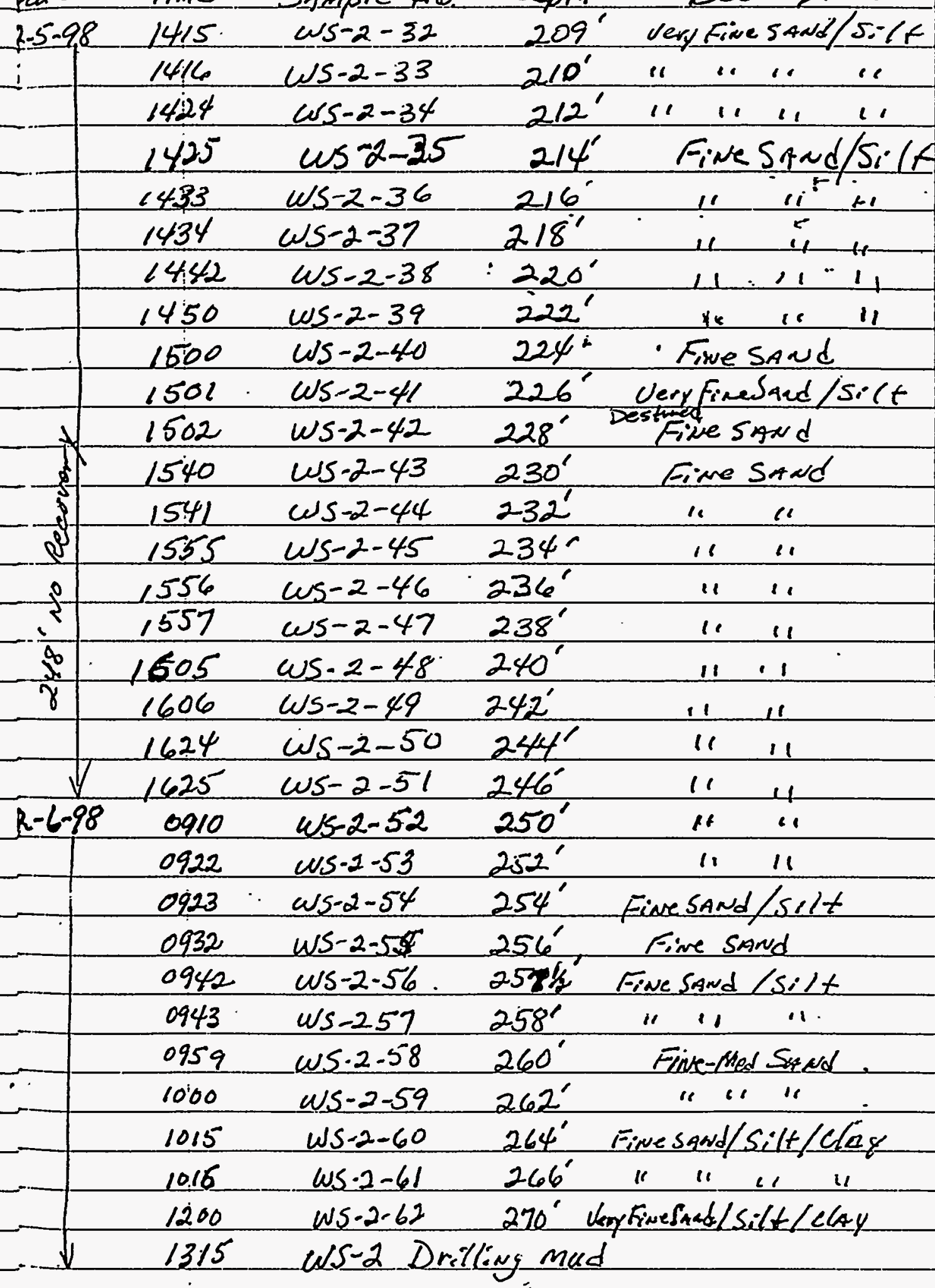


43

Date Time Sample Ind. Depth Description $-2 \cdot 10-9.8$.






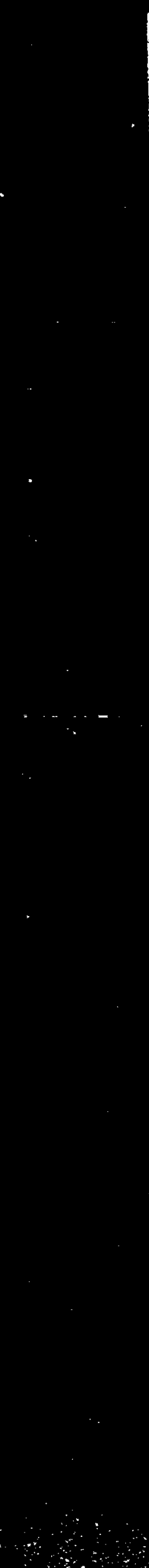

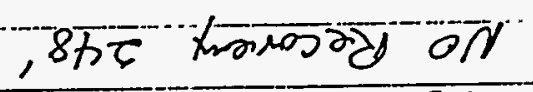

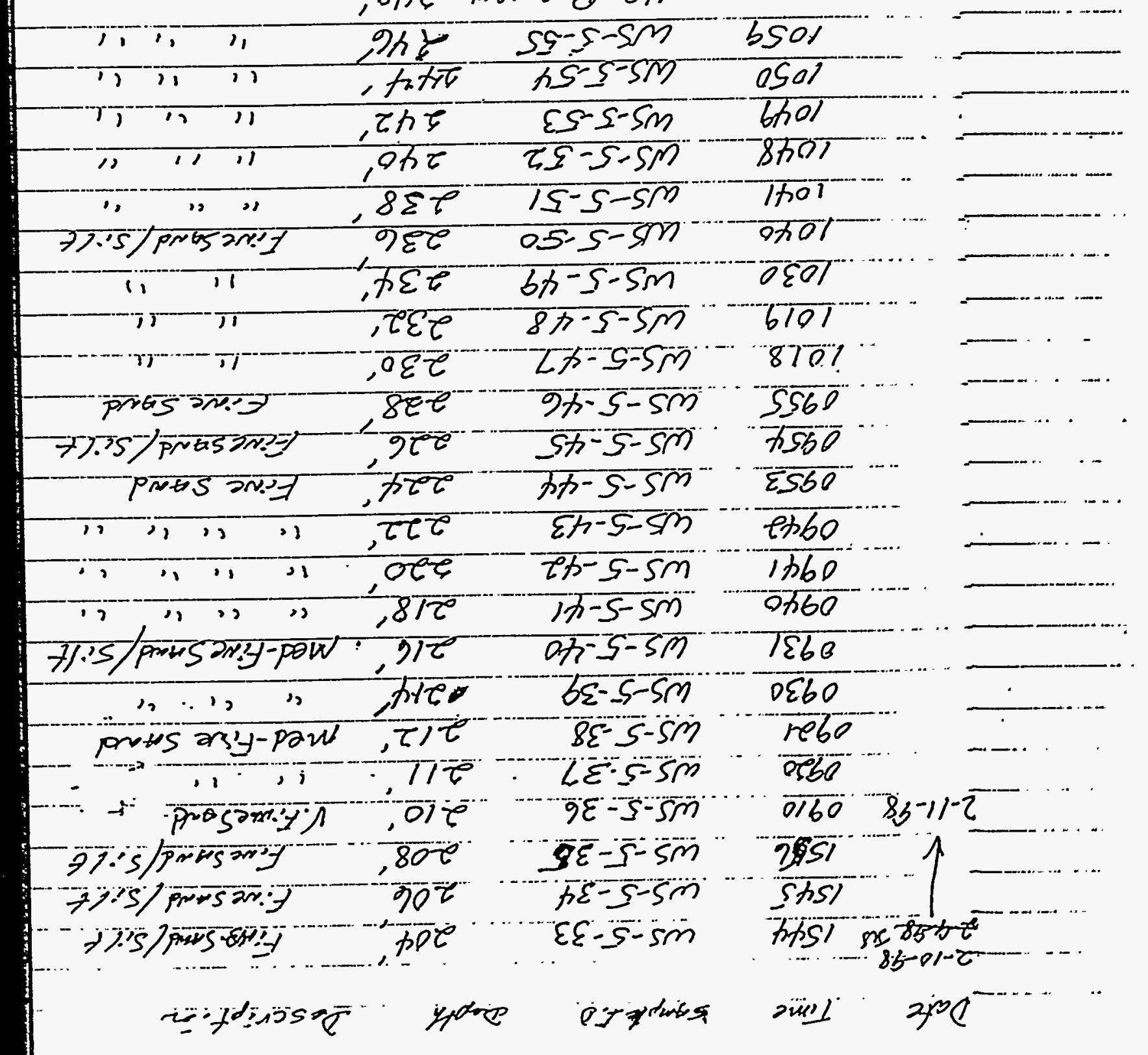

ip 


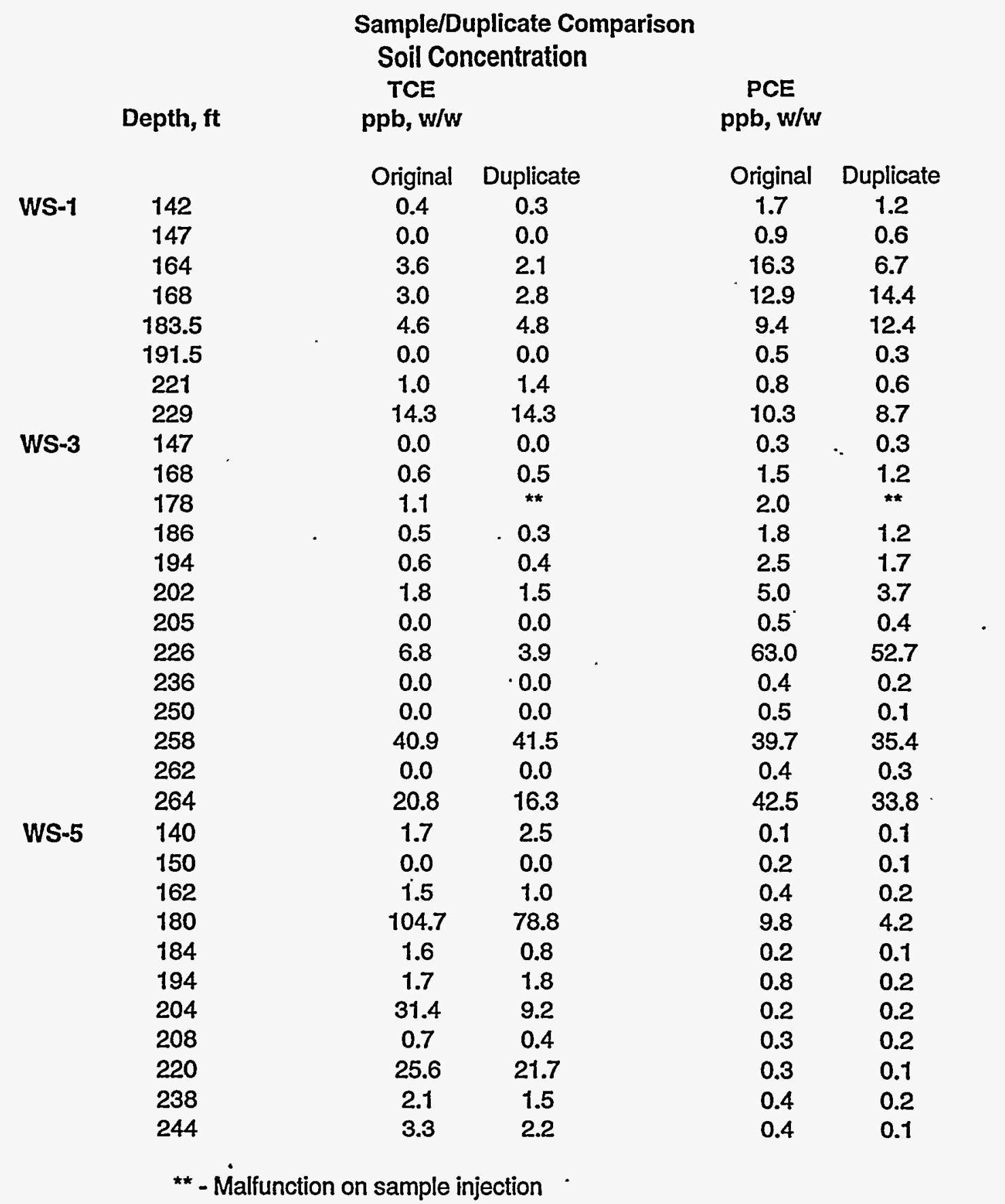




\section{APPENDIX E}

Atmospheric Monitoring/Investigation Derived Waste Field Screening Log 
OSR 25.10 (Re v6.18-92)
Stores: 26.15510 .00

ENGINEERING COMPUTATION SHEET

Title of Project Wester y sector characterization

Project No.

subject MON toping for VOes in breathing zane talley

( Mud and core

Works

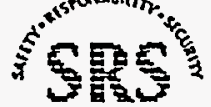

Date $11 / 28 / 98^{\circ}$ sheet No. 1

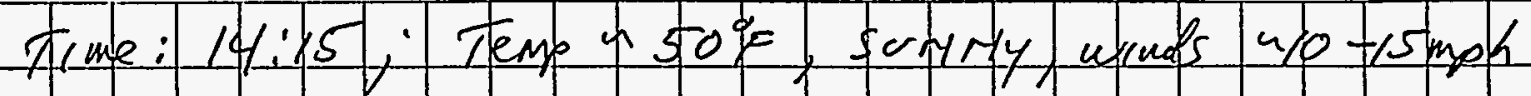

deration: wis -1

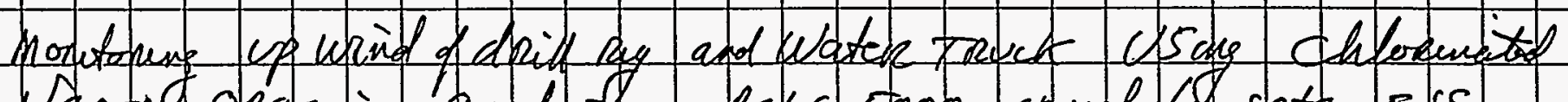

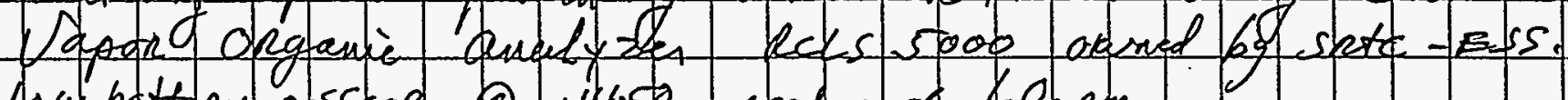

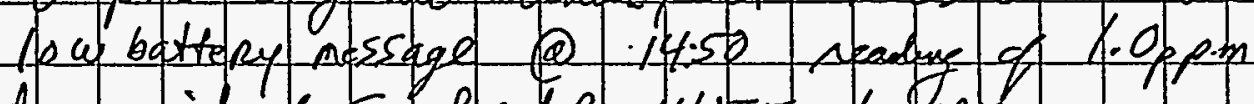

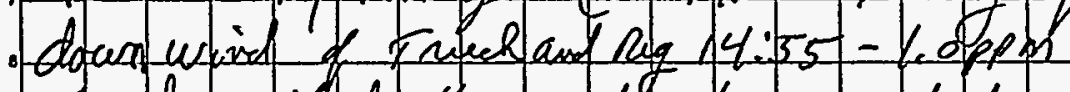

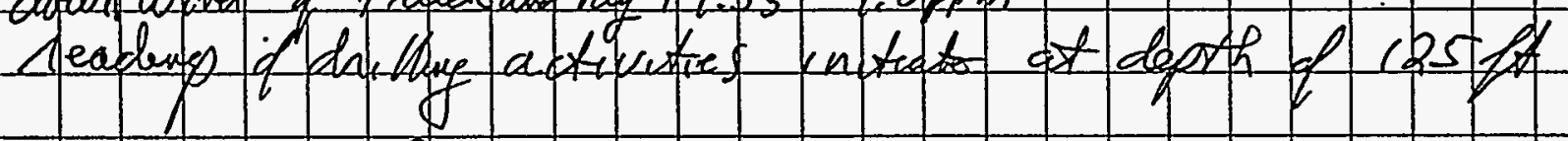

125 fat initial: 1458

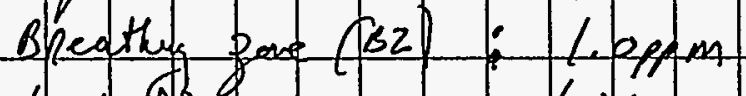

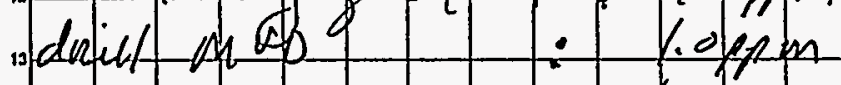

sample cone : hope

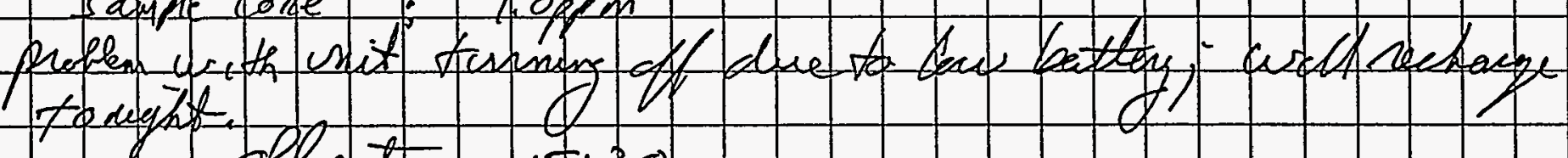

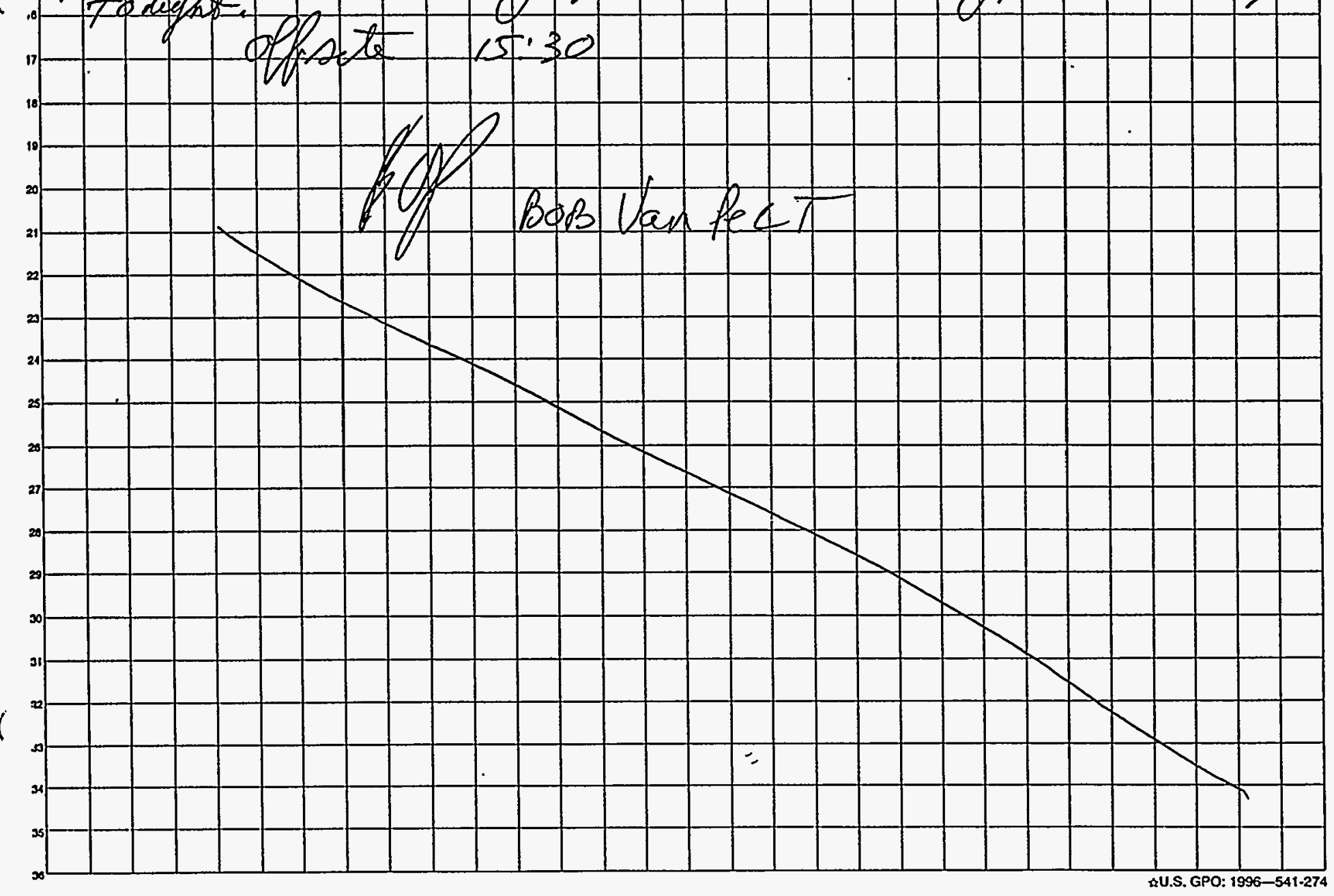

